3

\title{
Innervation modulates the functional connectivity between pancreatic endocrine cells
}

Yu Hsuan Carol Yang ${ }^{1 *}$, Linford J.B. Briant ${ }^{2}$, Christopher Raab ${ }^{1}$, Sri Teja Mullapudi ${ }^{1}$, HansMartin Maischein ${ }^{1}$, Koichi Kawakami ${ }^{3}$ and Didier Y.R. Stainier ${ }^{1 *}$

\footnotetext{
${ }^{1}$ Department of Developmental Genetics, Max Planck Institute for Heart and Lung Research,
} Bad Nauheim, Germany

${ }^{2}$ Oxford Centre for Diabetes, Endocrinology and Metabolism, Radcliffe Department of Medicine, University of Oxford, Oxford, United Kingdom

${ }^{3}$ Division of Molecular and Developmental Biology, National Institute of Genetics, Department of Genetics, SOKENDAI, Mishima, Japan

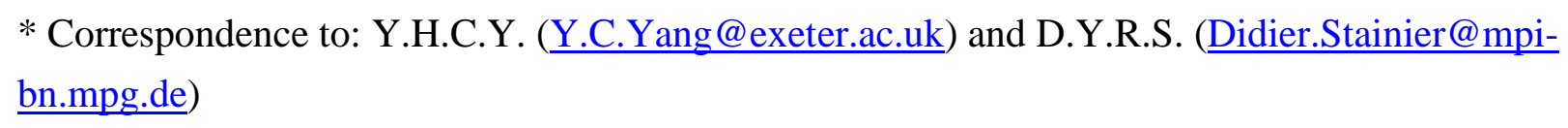

\section{Corresponding authors:}

Yu Hsuan Carol Yang, Ph.D.

Department III-Developmental Genetics, Max Planck Institute for Heart and Lung

Research, Ludwigstrasse 43, 61231 Bad Nauheim, Germany

E-mail: Carol.Yang@mpi-bn.mpg.de

Tel: $+49(0) 6032$ 705-1339

Current affiliation: Lecturer, Institute of Biomedical \& Clinical Science, University of Exeter

Medical School, RILD Building, Barrack Road, Exeter, EX2 5DW, United Kingdom

E-mail: $\underline{\text { Y.C.Yang@exeter.ac.uk }}$

1 Didier Y.R. Stainier, Ph.D.

2 Director, Department III-Developmental Genetics, Max Planck Institute for Heart and Lung

Research, Ludwigstrasse 43, 61231 Bad Nauheim, Germany

E-mail: Didier.Stainier@mpi-bn.mpg.de

Tel: +49(0)6032 705-1302

Fax: +49(0)6032 705-1304 


\section{Abstract}

Direct modulation of pancreatic endocrine cell activity by autonomic innervation has been debated. To resolve this question, we established an in vivo imaging model which also allows chronic and acute neuromodulation. Starting at a stage when zebrafish islet architecture is reminiscent of that in adult rodents, we imaged calcium dynamics simultaneously in multiple islet cell types. We first find that activity coupling between beta cells increases upon glucose exposure. Surprisingly, glucose exposure also increases alpha-alpha, alpha-beta and beta-delta coordination. We further show that both chronic and acute loss of nerve activity diminish activity coupling, as observed upon gap junction depletion. Notably, chronic loss of innervation severely disrupts delta cell activity, suggesting that delta cells receive innervation which coordinates its output. Overall, these data show that innervation plays a vital role in the establishment and maintenance of homotypic and heterotypic cellular connectivity in pancreatic islets, a process critical for islet function.

\section{Introduction}

Tight regulation of hormone release from pancreatic islets is critical for glucose homeostasis and its disruption can lead to diabetes mellitus ${ }^{1}$. Pancreatic islets are composed of different cell types, including the hormone producing alpha, beta and delta cells, peripheral nerves, and vascular endothelial and smooth muscle cells. Studies have implicated signaling from the vascular scaffold ${ }^{2,3}$ and nerve networks ${ }^{4-9}$ during the development and function of pancreatic islet cells. However, it remains difficult to investigate the immediate effects of acute nerve modulation on islet cell function. Given the alterations in islet innervation architecture in some models of diabetes ${ }^{10-12}$, it is imperative to understand whether disruption of nervous control can contribute to diabetes etiology.

Different methods of assessing islet cell function have provided important clues into the role of autocrine and paracrine signaling in this process. Electrophysiological recordings have provided fundamental insights into isolated islet cell function ${ }^{13-15}$, including functional connectivity studies that identified homotypic as well as heterotypic coupling between endocrine cells $^{16,17}$. However, assessing islet function in live animals with undisrupted vascular and nerve networks remains challenging. Calcium dynamics is a good readout of the function of all islet cell types because its influx is critical for hormone release. However, no studies to date have been able to record simultaneously the activity of all islet endocrine cell types in the intact organ of a living animal, which is required to understand how the different endocrine cell types respond to physiological perturbations individually and interdependently. To this end, we established an in vivo imaging platform to visualize the activity of all the islet cell types by combining calcium 
imaging with cell type reporters. We investigated the functional connectivity between homotypic and heterotypic cell pairs by analyzing the correlation patterns in their intracellular calcium changes. Chronic and acute inhibition of nerve activity captured its dynamic control of the functional connectivity between islet endocrine cells, which is in part dependent on gap junctions.

\section{Results and discussion}

\section{The activity of all pancreatic endocrine cell types can be studied simultaneously in vivo}

The zebrafish primary islet becomes highly innervated ${ }^{7}$ and vascularized ${ }^{3,18,19}$ early in development (Figure 1A). Fluorescent reporters for different pancreatic endocrine cell types, including beta, alpha, and delta cells, were used to study the establishment of islet cytoarchitecture (Figure 1B). By 100 hours post fertilization (hpf), a beta cell core and alpha cell mantle layout is observed (Figure 1B-C), reminiscent of adult rodent islets ${ }^{20}$ and small human islets $^{21}$. Simultaneous functional assessment of all islet cell types in vivo required reporters for cell activity and cell identity. We used the Et(1121A:GALAFF) enhancer trap line with the Tg(UAS:GCaMP6s) line for calcium imaging of all islet cells (Figure 1D-E, Figure 1- Movie Suppl. 1), as well as the $T g($ ins:mCardinal) and $T g(s s t 2: R F P)$ lines to assign beta and delta cell identity, respectively; alpha cells were identified by their mantle localization and/or by immunostaining (Figure 1E). Thus, for the first-time, we were able to assess the activity of all islet cells in their native environment in an intact living animal (Figure. 1F, Figure 1- Movie Suppl. 2).

\section{Homotypic and heterotypic coupling between endocrine cells requires pancreatic innervation}

Activity coupling between pancreatic endocrine cells can be mediated by autocrine and paracrine signaling, gap junctions, and other means. To investigate whether pancreatic innervation is critical for intra-islet coordination of activity, we used different approaches to chronically or acutely inhibit neural signaling. We used endoderm transplantation to generate chimeric zebrafish that express two GAL4/UAS systems in different germ layer-derived tissues and investigated the role of chronic neural inhibition on islet function (Figure 2A). Pan-neural expression of botulinum toxin (BoTx) chronically inhibits neurotransmitter release ${ }^{7,22}$ and leads to elevated glucose levels at $100 \mathrm{hpf}^{7}$ (Figure 2B). While primary islet volume was consistently greater in $\mathrm{BoTx}^{+}$larvae at $100 \mathrm{hpf}$ (Figure 2C; as we have described for earlier stages ${ }^{7}$ ), we did not observe changes in the architectural arrangement of the different islet cell types (Figure 2D). From the normalized single cell calcium traces, the correlation matrices, and average correlation coefficients $\left(\mathrm{R}_{\mathrm{avg}}\right)$, we observed that the calcium dynamics in $\mathrm{BoTx}^{+}$larvae were significantly 
disrupted, with impairment in beta cell coupling (Figure $2 \mathrm{E}-\mathrm{G})$. Our measure of $\mathrm{R}_{\mathrm{avg}}$ over increasing intercellular distance also revealed severe disruption in $\mathrm{BoTx}^{+}$larvae, indicating drastically altered synchronicity and wave propagation (Figure $2 \mathrm{H}-\mathrm{I}$ ). To determine how dysfunctional neural signaling influenced communication between different endocrine cell types, we conducted fraction time analysis of heterotypic cell pairs that were in nearest proximity to each other. We reasoned that nearest neighbours have a greater likelihood of displaying coupling, which would be evident by analyzing activity patterns between heterotypic cell pairs. We analyzed the single cell calcium traces and determined the fraction of time a given cell pair resides in a state when 1) one cell was silent, the other active, 2) both cells were active, and 3) both cells were silent. This analysis provided insights into the neural regulation of heterotypic intercellular communication. Aside from the quiet phase, when both cell types were silent, we found changes in activity patterns between delta-beta, alpha-delta, and alpha-beta cell pairs (Figure 2J-L): upon chronic neural inhibition, the delta-silent/beta-active state was decreased while the delta-active/beta-silent state (Figure 2J) and the delta-active/alpha-silent state (Figure $2 \mathrm{~K}$ ) were both increased. Overall, chronic neural inhibition resulted in the hyperactivation of delta cells, and somatostatin released from delta cells likely inhibited both beta and alpha cell activity. We also found a significant decrease in the alpha-active/beta-active state upon chronic neural inhibition (Figure 2L). With growing evidence of local glucagon signaling in potentiating beta cell activity ${ }^{23}$, this finding further suggests that neural regulation may be an important regulator of alpha-beta connectivity.

Given the potential role of pancreatic innervation on islet cell maturation, we next investigated the effects of acutely blocking neural activity using two different approaches. By lineage tracing, we found that the neural crest derived peri-islet neurons were also labelled by the Et(1121A:GAL4FF) enhancer trap (Figure 3A-B), thereby allowing us to investigate the effects of photo-ablating a subset of peri-islet neurons on islet cell activity (Figure 3C). While the oscillatory pattern of calcium dynamics was maintained in beta cells upon this ablation (Figure 3D), the coupling between beta cells was significantly decreased (Figure 3E-F). Notably, we did not observe further impairment in beta cell wave propagation (Figure 3G-H), suggesting that upon ablation of peri-islet neurons, the signal that initiated beta cell waves was blunted while the beta cells maintained their propensity for calcium wave propagation. Unlike in the chronic neural inhibition scenario, delta-beta and alpha-delta coupling was not affected upon ablating peri-islet neurons (Figure 3I-J). However, we observed a trend towards a decrease in the alphaactive/beta-active state (Figure $3 \mathrm{~K}$ ). Overall, ablation of peri-islet neurons significantly disrupted beta-beta connectivity, while conclusions regarding heterotypic interactions in this model will require further investigations into the various neural subsets that were targeted. It is 
likely that our targeting of peri-islet neurons did not always ablate the specific neurons that guide the activity coupling between alpha and beta cells.

Next, we took an optogenetic approach by generating a transgenic line that allows one to acutely photo-inhibit the release of neurotransmitters with a single pulse of blue light. This method has previously been used in Drosophila ${ }^{24}$ and C. elegans $^{25,26}$ for targeted photo-ablation and photo-inhibition. Pan-neural expression of a singlet oxygen generator, miniSOG2, tethered to synaptic granules resulted in a blue light inducible loss of swimming activity in $110 \mathrm{hpf}$ larvae (Figure 4-Fig. Suppl. 1A-C). Following this confirmation of the effectiveness of the tool, we studied neural control of islet cell activity upon acute photo-inhibition (Figure 4 - Fig. Suppl. 1D). Surprisingly, photo-inhibition decreased glucose levels compared to transgene-negative fish exposed to the same light condition (Figure 4A). Similar to peri-islet neural ablation, pan-neural photo-inhibition decreased beta cell connectivity (Figure 4B-D), while beta cell wave propagation was not impaired (Figure 4E-F). Changes in delta-beta and alpha-beta heterotypic interactions was observed upon acute neural inhibition (Figure 4G-I). A significant decrease in delta-silent/beta-active state reflects what we observed upon chronic neural inhibition (Figure $4 \mathrm{G})$. Like photo-ablation of peri-islet neurons, no changes in alpha-delta interactions were observed (Figure 4H). Notably, following acute neural inhibition both alpha-silent/beta-active and alpha-active/beta-active states were significantly decreased, while alpha-active/beta-silent and alpha-silent/beta-silent states were significantly increased (Figure 4I). These changes in alpha-beta interactions were consistently observed upon both chronic and acute pan-neural inhibition, possibly reflecting a role for neurons in the maintenance of alpha-beta coupling.

\section{Gap junctions are required for beta cell coupling}

Could innervation act as the upstream trigger for activity coupling while other means of intercellular communication propagate the signals across the islet? Gap junctions have well described roles in mediating coordination of beta cell activity and insulin secretion ${ }^{27,28}$. In mammals, $c x 36$ encoded gap junctions mediate the majority of the functional coupling between beta cells ${ }^{29-31}$. While previous reports have described the lack of beta cell expression of the zebrafish homolog $c x 35^{32}$, we found that $c x 43$ is highly expressed in zebrafish beta cells by 100 hpf (Figure 5A, Figure 5 - Fig. Suppl. 1). Connexin 43 has known roles in mediating bone growth and regeneration in zebrafish ${ }^{33-35}$, however no pancreatic defects have been reported in these loss-of-function studies. We used animals harboring a cx43 mutation in the exon encoding the second extracellular loop and that has been proposed to interfere with connexon docking between neighbouring cells ${ }^{36}$, to elucidate the role of $c x 43$ in beta cells (Figure 5B). While $c x 43^{+/}$and $c x 43^{-/}$larvae do not exhibit gross phenotypic defects at 100 hpf (Figure 5 - Fig. Suppl. 2A-B), a subset of them (23.5\% and $17.9 \%$, respectively) display elevated glucose levels 
(Figure 5-Fig. Suppl. 2C), which is likely an underestimation of the true penetrance of this phenotype due to the pooling of animals required for the assay. Since islet architecture in $c x 43^{+/-}$ and $c \times 43^{-/}$larvae at $100 \mathrm{hpf}$ appeared unaffected (Figure 5C), we next assessed the activity coupling between beta cells. From normalized single cell calcium traces, we observed blunted glucose-induced coupling of beta cell activity in $c \times 43^{+/-}$and $c \times 43^{-/-}$larvae (Figure 5D, Figure 5 Movie Suppl. 1). This finding was confirmed in the correlation matrices (Figure 5E) and average correlation coefficients $\left(\mathrm{R}_{\mathrm{avg}}\right.$; Figure $\left.5 \mathrm{~F}\right)$. While we did not observe a complete penetrance of this phenotype, there was a significant decrease in $\mathrm{R}_{\text {avg }}$ following high glucose treatment in $c \times 43^{+/-}$ larvae (Figure 5F). Given the reduced coupling between beta cells in the entire islet, we next analyzed whether coupling changes relative to intercellular distance. The greater decrease in $\mathrm{R}_{\mathrm{avg}}$ with increasing cellular distance observed in $c x 43^{-/}$larvae (Figure 5G-H) indicates that the propagation of calcium waves across the islet was significantly impaired upon loss of Cx43 function. Given that some coupling was maintained between beta cells in $c x 43^{-/}$larvae, it is likely that pancreatic innervation could be mediating the remaining intra-islet coordination of activity.

Fraction time analysis of heterotypic cell pairs determined how dysfunctional Cx43 gap junctions influenced the other islet cell types (Figure 5 - Fig. Suppl. 2D-F). While no significant changes were observed between alpha-delta and alpha-beta activity patterns, a significant increase in delta-silent/beta-active state was observed in $c \times 43^{+/-}$and $c \times 43^{-/-}$larvae (Figure 5 Fig. Suppl. 2D). Given that $c x 43$ expression is weakly detected in delta cells, it may also be important in mediating the communication between delta and beta cells. Indeed, gap junction mediated beta to delta electrical coupling has been proposed to activate glucose induced delta cell activation, at least in part ${ }^{17}$, and we found a significant decrease in the delta-active/betaactive state in $c x 43^{+/}$larvae (Figure 5 - Fig. Suppl. 2D). Interestingly $c x 43$ expression is absent in adult beta and delta cells ${ }^{37}$ (Figure 5 - Fig. Suppl. 1), yet we observed severe fasting hypoglycemia in $c x 43^{+/}$and $c x 43^{-/-}$adults (Figure 5 - Fig. Suppl. 2G). Whether dysfunctional Cx43-mediated gap junctional coupling between beta-beta and delta-beta cells early in life influences glucose homeostasis in adults warrants further studies.

Dissecting the complex interplay of local autocrine, paracrine, and gap junctional communication between different endocrine cells, in addition to vascular and nerve interactions, is often hindered by our ability to simultaneously study them in an intact organ within its innate environment. Imaging calcium dynamics with genetically encoded biosensors or calcium sensitive fluorescent indicators in individual islet cell types has been conducted in vitro with dispersed cells $^{38,39}$, whole islets ${ }^{40,41}$, and perfused pancreas slices ${ }^{42,43}$, and in vivo with islets transplanted into the anterior chamber of the eye ${ }^{4,44}$, and intravital imaging of mouse pancreas ${ }^{45}$. We report a non-invasive in vivo imaging strategy to study all the different pancreatic endocrine 
cell types within the same animal. Our three approaches to inhibit neural control, ranging in temporal and spatial specificity, provided useful insights into the role of neurons in regulating pancreatic islet function. Activity coupling between beta cells is in part mediated by $\mathrm{Cx} 43$ gap junctions, and neural regulation is critical for the establishment and maintenance of beta cell connectivity as we consistently found decreased beta cell coupling upon chronic and acute neural inhibition. Given that our targeted neural ablation approach also led to this decline in beta cell coupling, it is likely that autonomic neural control is required for beta cell connectivity independently of indirect effects resulting from neural regulation of other organs. It has been proposed that glucose sensing neurons regulate early postnatal beta cell proliferation and maintenance of beta cell function ${ }^{9}$, and our data support the peri-islet localization of such neurons.

We have focused on the pancreatic beta, alpha, and delta cells; however, it is important to note that there are other endocrine cell types (gamma and epsilon cells) that remain undefined in our study, but do display glucose induced activity coupling with beta cells (Figure 2F). Fraction time analysis allowed us to study activity patterns of heterotypic cell pairs that are near each other upon loss of $\mathrm{Cx} 43$ or neural signaling. We found changes in delta-beta activity patterns, supporting a role for gap junctions in mediating electrical coupling between delta and beta cells ${ }^{17}$. Both chronic and acute neural inhibition blunted the functional connectivity between alpha and beta cells suggesting that neurons may have an important role in the paracrine potentiation of beta cell activity by glucagon released from alpha cells ${ }^{23}$. We propose that alphabeta interactions are specifically regulated by pancreatic innervation, since peri-islet neural ablation also led to a similar decreasing trend in the alpha-active/beta-active state. However, given that pan-neural inhibition is required to induce changes in delta-beta interactions, it is possible that central nervous control of other organs could in part be driving these changes. Importantly, our data further support the role of neurons in modulating delta cell activity and maturation, given that hyperactivity likely reflects uncontrolled release of somatostatin and the delta cell hypertrophy and decreased delta cell mass we previously described ${ }^{7}$.

Selective targeting of subsets of neurons will advance our understanding of the pancreatic islet-neural interplay in health and disease, including diabetes pathophysiology. Through our in vivo studies of homotypic and heterotypic activity coupling, we have illustrated how studying functional connectivity can be achieved for the endocrine pancreas and discovered a critical role for neurons in mediating these connections. Given the cellular heterogeneity of organ composition, simultaneously evaluating the function of the different cell types that make up an organ provides insights that can be missed by simply investigating one cell type at a time. Interrogating the neural regulation of other organs, such as the liver, intestine, and kidney, can be achieved through the extended application of these tools. In combination with the ability to 
252 monitor organ development, function, and regeneration in vivo, this approach will allow one to

253 address difficult questions pertaining to the autonomic nervous system and its role in organ

254 maintenance and dysfunction.

255

256

257

Materials and methods

258 Zebrafish transgenic lines and husbandry

259 All zebrafish husbandry was performed under standard conditions in accordance with

260 institutional (MPG) and national ethical and animal welfare guidelines. Adult zebrafish were fed

261 a combination of fry food (Special Diet Services) and brine shrimp five times daily and

262 maintained under a light cycle of 14 hours light : 10 hours dark at $28.5^{\circ} \mathrm{C}$. Zebrafish embryos

263 and larvae were grown in egg water at $28.5^{\circ} \mathrm{C}$. Transgenic and mutant lines used were on the

264 mitfa ${ }^{w 2 / w 2}$ background and as described in Table 1.

265

Table 1. List of zebrafish transgenic and mutant lines

\begin{tabular}{|c|c|c|}
\hline Name & Specificity/Purpose/Phenotype & Reference \\
\hline \multicolumn{3}{|l|}{ Tissue specific promoter lines } \\
\hline Et(1121A:GALAFF) $)^{\text {nkgsaizgffm1121a }}$ & Pancreatic islet cells, neurons & current \\
\hline $\operatorname{Tg}(\text { ins: } m \text { Cardinal })^{\text {bns } 162}$ & Pancreatic beta cells & current \\
\hline Tg(elavl3:sypb-miniSOG2-P2A-mScarlet $)^{b n s 529}$ & Inhibit post-mitotic neurons & current \\
\hline $\operatorname{Tg}\left(\right.$ elavl3:GAL4-VP16) ${ }^{z f 357}$ & Post-mitotic neurons & 46 \\
\hline $\operatorname{Tg}(\text { sst } 2: R F P)^{g z 19}$ & Pancreatic delta cells & 47 \\
\hline $\operatorname{Tg}(\operatorname{gcga}: G F P)^{i a l}$ & Pancreatic alpha cells & 48 \\
\hline $\operatorname{Tg}(\text { sox 10:CreERT2, myl7:GFP) })^{t 007}$ & Neural crest cells, heart marker & 49 \\
\hline$T g(u b b: \operatorname{lox} P-C F P-l o x P-n u c-m C h e r r y)^{j h 63}$ & Ubiquitous & 50 \\
\hline$T g(k d r l: E G F P)^{s 843}$ & Endothelial cells & 51 \\
\hline \multicolumn{3}{|l|}{ UAS lines } \\
\hline $\operatorname{Tg}(U A S: G C a M P 6 s)^{U A S h s p z G C a M P 6 s}$ & Visualize intracellular calcium & 52 \\
\hline $\operatorname{Tg}(U A S: B o T x B L C-G F P)^{i c m 21}$ & Inhibit neurotransmitter release & 7,22 \\
\hline \multicolumn{3}{|l|}{ Mutant lines } \\
\hline$c x 43^{j 7 e 2}$ & Lacking $c \times 43$ gap junctions & 36 \\
\hline
\end{tabular}


Tg(elavl3:sypb-miniSOG2-P2A-mScarlet) line was generated by Tol2 transgenesis of $8.7 \mathrm{~kb}$ elavl3 promoter (Addgene: 59531, AgeI restriction enzyme digested) driving expression of sypb (Addgene: 74316), miniSOG2 (Addgene: 87410), P2A-mScarlet (gift from A. Beisaw) cloned with Cold Fusion (System Biosciences). Tg(ins:mCardinal) line was generated by Tol2 transgenesis of $1.1 \mathrm{~kb}$ ins promoter (in-house plasmid, MluI restriction enzyme digested) driving expression of $m$ Cardinal (Addgene: 51311) cloned with Cold Fusion.

275

Generation of chimeric zebrafish

277 Et(1121A:GAL4FF); Tg(UAS:GCaMP6s); Tg(sst2:RFP); Tg(ins:mCardinal) donor embryos were injected with 200 pg sox32 mRNA, generated with mMESSAGE mMACHINE TM SP6 transcription kit (Thermo), at the one-cell-stage to enhance endoderm formation. morpholino (Gene Tools LLC) at the one-cell-stage to deplete endoderm formation. At the 1000-cell-stage, single cells were removed from donor embryos with a glass capillary needle, and $\sim 40$ cells were transplanted into host embryos in the region fated to become endodermderived tissues. Only larvae that displayed complete endoderm transplant, without obvious defects, and carried the relevant transgenes were used for downstream imaging experiments. Control chimeras were negative for BoTxBLC-GFP expression.

\section{In vivo confocal microscopy}

Live zebrafish between $100-110$ hours post fertilization were anesthetized with $0.015 \%$ Tricaine and mounted in $0.8 \%$ low melting agarose in egg water containing $0.005 \%$ Tricaine for confocal imaging. Zeiss LSM880 upright laser scanning confocal microscopes equipped with a PlanApochromat 20x/NA1.0 dipping lens was used for imaging. Time-lapse calcium imaging was conducted in $25^{\circ} \mathrm{C}$ conditions and z-stacks were taken at $5 \mathrm{~s}$ intervals for 1-2 hr. Larvae were exposed to $75 \mathrm{mM}$ glucose containing egg water at the indicated time points during the timelapse imaging to increase whole larvae glucose levels within a physiological range (Figure 2 GCaMP6s signal was visualized with an Argon laser at $488 \mathrm{~nm}$.

\section{Two-photon laser ablation}

A Chameleon Vision II Ti:Sapphire Laser (Coherent) mounted on a Zeiss LSM880 microscope was used for two-photon single-cell laser ablation of peri-islet neurons labelled by the Et(1121A:GAL4FF) enhancer trap. The tunable laser was set at $800 \mathrm{~nm}$ to scan an ablation area 
min before continuation of calcium imaging. Controls were mock ablation of cells within $20 \mu \mathrm{m}$ from the peri-islet neurons. Animals from the same clutch were randomly assigned to ablation and control groups.

\section{Photo-inhibition of nerve activity}

All experiments with Tg(elavl3:sypb-miniSOG2-P2A-mScarlet) were done on F1 to F3 larvae displaying strong and uniform $\mathrm{mScarlet}$ signal. Controls were transgene-negative siblings. For assessing swimming behavior, $110 \mathrm{hpf}$ larvae were individually isolated in $9 \mathrm{~mm}$ diameter circular wells filled with $200 \mu \mathrm{l}$ egg water. A Nikon SMZ25 stereomicroscope with a P2-SHR PlanApo 1x/NA0.15 objective was used for time-lapse imaging of larvae at $1 \mathrm{~s}$ intervals, the same animals were imaged pre-light and post exposure to a 5 min pulse of blue light $(3.8 \mathrm{~mW}$ LED, 466/40 filter, Lumencor Sola Light Engine). For assessing changes in glucose levels, pools of 40 larvae swimming in $9 \mathrm{~cm}$ diameter petri-dishes filled with $35 \mathrm{~mL}$ egg water were exposed to $0.3 \mathrm{~mW}$ blue LED light for 30 min prior to sample collection, control animals were not exposed to blue light and were randomly selected siblings from the same clutch. Notably, acute blue light exposure alone mildly reduced swimming behaviour and increased glucose levels (Figure 4 - Fig. Suppl. 1C, Figure 4A). Induction of a stress response likely led to this increase in glucose levels in wild-type larvae, as chronic $14 \mathrm{hr}$ exposure to blue LED light for 3 consecutive days kills zebrafish larvae ${ }^{53}$. For assessing calcium changes, larvae were exposed to a 3 min pulse of blue light (2.1 mW $470 \mathrm{~nm}$ LED, Colibri) and GCaMP6s signal was measured pre- and post-blue light exposure. While blinding was not possible, we randomized the order in which animals on a given day were imaged.

\section{Wholemount immunostaining}

Zebrafish were euthanized with tricaine overdose prior to overnight fixation in $4 \%$ paraformaldehyde dissolved in PBS containing $120 \mu \mathrm{M} \mathrm{CaCl}_{2}$ and $4 \%$ sucrose, pH7.4. The skin was manually removed with forceps, without disturbing the internal organs and the zebrafish were permeabilized with $1 \%$ TritonX-100, 1\% DMSO containing PBS for $3 \mathrm{~h}$ at room temperature for most staining protocols. For cx43 staining, antigen retrieval with $150 \mathrm{mM}$ Tris$\mathrm{HCl} \mathrm{pH} 9$ at $70^{\circ} \mathrm{C}$ for $15 \mathrm{~min}$ and acetone permeabilization at $-20^{\circ} \mathrm{C}$ for $20 \mathrm{~min}$ was performed. Following blocking with 5\% donkey serum (Jackson Immunoresearch) in blocking buffer (Dako), samples were incubated in primary antibodies overnight at $4{ }^{\circ} \mathrm{C}$, washed $4 \mathrm{x}$ with $0.025 \%$ TritonX-100 containing PBS, incubated in secondary antibodies overnight at $4{ }^{\circ} \mathrm{C}$, washed $4 \mathrm{x}$, incubated in an increasing glycerol gradient of $25 \%, 50 \%$, and $75 \%$, and mounted in VectorShield mounting medium. The following antibodies and dilutions were used: mouse antiglucagon (1:200, Sigma G2654), chicken anti-GFP (1:200, Aves GFP-1020), mouse anti- 
acetylated Tubulin (1:200, Sigma T7451), rabbit anti-connexin 43 (1:100, Sigma C6219). Secondary antibodies used in this study include donkey anti-rabbit AlexaFluor568 (1:400, Thermo A10042) and AlexaFluor488 (1:300, Jackson 711-545-152), donkey anti-mouse AlexaFluor488 (1:300, Jackson 715-545-150) and AlexaFluor647 (1:200, Jackson 715-605-150), donkey anti-chicken AlexaFluor488 (1:300, Jackson 703-545-155). Nuclei were stained with 25 $\mu \mathrm{g} / \mathrm{ml}$ DAPI (Sigma). Images were taken on Zeiss LSM880 or LSM800 laser scanning confocal microscopes equipped with a $25 \mathrm{x} / \mathrm{NA} 0.8$ objective.

\section{Data analysis}

Image data were analyzed using Imaris (Bitplane) and Fiji (ImageJ). Correlation and fraction time analysis was performed using Matlab (code available upon request). Statistical analysis was performed using Prism 8 (GraphPad). D’Agostino \& Pearson test was used to assess Gaussian distribution of the data and subsequent selection of parametric or nonparametric tests. For comparison between two groups, a two-tailed Student's $t$-test or a Mann-Whitney test was used, respectively, to determine the p-values. For comparison between more than two groups, an ordinary one-way ANOVA with Holm-Sidak's multiple comparisons test or a Kruskal-Wallis test with Dunn's multiple comparisons test was used, respectively, to determine the p-values. The number of animals or cells analyzed, and the p-values are reported in the figure and figure legends. All experiments were repeated on different days using at least three different clutches of animals.

\section{Acknowledgments}

These studies were supported by funds from the Max Planck Society to D.Y.R.S. Y.H.C.Y was supported by CIHR Postdoctoral Fellowships, an HFSP Long-Term Fellowship, an EMBO Long-Term Fellowship, and NIG-JOINT funding. L.J.B.B. was supported by a Sir Henry Wellcome Postdoctoral Fellowship. K.K. was supported by an NBRP grant from AMED. We thank Arica Beisaw for the plasmid with P2A-mScarlet and James Johnson for critical reading of the manuscript. The referenced $c \times 43$ mutant line was generously provided by Matthew Harris.

\section{Author contributions}

Y.H.C.Y. conceived the study, designed/performed the research, analyzed data, and wrote the manuscript. L.J.B.B. analyzed data, provided critical feedback and edited the manuscript. C.R., 
Tg(UAS:GCaMP6s) lines and edited the manuscript. D.Y.R.S. provided the resources and critical feedback, and edited the manuscript.

\section{Competing interests}

The authors have no competing interests to declare.

\section{References}

1. Noguchi, G.M. \& Huising, M.O. Integrating the inputs that shape pancreatic islet hormone release. Nat Metab 1, 1189-1201 (2019).

2. Almaca, J. et al. Young capillary vessels rejuvenate aged pancreatic islets. Proc Natl Acad Sci U S A 111, 17612-17617 (2014).

3. Mullapudi, S.T. et al. Disruption of the pancreatic vasculature in zebrafish affects islet architecture and function. Development 146 (2019).

4. Rodriguez-Diaz, R. et al. Noninvasive in vivo model demonstrating the effects of autonomic innervation on pancreatic islet function. Proc Natl Acad Sci U S A 109, 2145621461 (2012).

5. Taborsky, G.J., Jr., Ahren, B. \& Havel, P.J. Autonomic mediation of glucagon secretion during hypoglycemia: implications for impaired alpha-cell responses in type 1 diabetes. Diabetes 47, 995-1005 (1998).

6. Borden, P., Houtz, J., Leach, S.D. \& Kuruvilla, R. Sympathetic innervation during development is necessary for pancreatic islet architecture and functional maturation. Cell Rep 4, 287-301 (2013).

7. Yang, Y.H.C., Kawakami, K. \& Stainier, D.Y. A new mode of pancreatic islet innervation revealed by live imaging in zebrafish. Elife 7 (2018).

8. Makhmutova, M. et al. Pancreatic Islets Communicate With the Brain <em>via</em> Vagal Sensory Neurons. bioRxiv, 780395 (2019).

9. Tarussio, D. et al. Nervous glucose sensing regulates postnatal beta cell proliferation and glucose homeostasis. J Clin Invest 124, 413-424 (2014).

10. Mundinger, T.O. \& Taborsky, G.J., Jr. Early sympathetic islet neuropathy in autoimmune diabetes: lessons learned and opportunities for investigation. Diabetologia 59, 2058-2067 (2016).

11. Mundinger, T.O. et al. Human Type 1 Diabetes Is Characterized by an Early, Marked, Sustained, and Islet-Selective Loss of Sympathetic Nerves. Diabetes 65, 2322-2330 (2016).

12. Tang, S.C. et al. Human pancreatic neuro-insular network in health and fatty infiltration. Diabetologia 61, 168-181 (2018).

13. Vergari, E. et al. Somatostatin secretion by $\mathrm{Na}(+)$-dependent $\mathrm{Ca}(2+)$-induced $\mathrm{Ca}(2+)$ release in pancreatic delta-cells. Nat Metab 2, 32-40 (2020).

14. Camunas-Soler, J. et al. Patch-Seq Links Single-Cell Transcriptomes to Human Islet Dysfunction in Diabetes. Cell Metab 31, 1017-1031 e1014 (2020). 
15. Hastoy, B. et al. Electrophysiological properties of human beta-cell lines EndoC-betaH1 and -betaH2 conform with human beta-cells. Sci Rep 8, 16994 (2018).

16. Moreno, A.P., Berthoud, V.M., Pérez-Palacios, G. \& Pérez-Armendariz, E.M. Biophysical evidence that connexin-36 forms functional gap junction channels between pancreatic mouse beta-cells. Am J Physiol Endocrinol Metab 288, E948-956 (2005).

17. Briant, L.J.B. et al. delta-cells and beta-cells are electrically coupled and regulate alphacell activity via somatostatin. J Physiol 596, 197-215 (2018).

18. Hen, G. et al. Venous-derived angioblasts generate organ-specific vessels during zebrafish embryonic development. Development 142, 4266-4278 (2015).

19. Toselli, C.M., Wilkinson, B.M., Paterson, J. \& Kieffer, T.J. Vegfa/vegfr2 signaling is necessary for zebrafish islet vessel development, but is dispensable for beta-cell and alpha-cell formation. Sci Rep 9, 3594 (2019).

20. Brereton, M.F., Vergari, E., Zhang, Q. \& Clark, A. Alpha-, Delta- and PP-cells: Are They the Architectural Cornerstones of Islet Structure and Co-ordination? J Histochem Cytochem 63, 575-591 (2015).

21. Bonner-Weir, S., Sullivan, B.A. \& Weir, G.C. Human Islet Morphology Revisited: Human and Rodent Islets Are Not So Different After All. J Histochem Cytochem 63, 604-612 (2015).

22. Sternberg, J.R. et al. Optimization of a Neurotoxin to Investigate the Contribution of Excitatory Interneurons to Speed Modulation In Vivo. Curr Biol 26, 2319-2328 (2016).

23. Svendsen, B. et al. Insulin Secretion Depends on Intra-islet Glucagon Signaling. Cell Rep 25, 1127-1134 e1122 (2018).

24. Makhijani, K. et al. Precision Optogenetic Tool for Selective Single- and Multiple-Cell Ablation in a Live Animal Model System. Cell Chem Biol 24, 110-119 (2017).

25. Lin, J.Y. et al. Optogenetic inhibition of synaptic release with chromophore-assisted light inactivation (CALI). Neuron 79, 241-253 (2013).

26. Qi, Y.B., Garren, E.J., Shu, X., Tsien, R.Y. \& Jin, Y. Photo-inducible cell ablation in Caenorhabditis elegans using the genetically encoded singlet oxygen generating protein miniSOG. Proc Natl Acad Sci U S A 109, 7499-7504 (2012).

27. Farnsworth, N.L. \& Benninger, R.K. New insights into the role of connexins in pancreatic islet function and diabetes. FEBS Lett 588, 1278-1287 (2014).

28. Head, W.S. et al. Connexin-36 gap junctions regulate in vivo first- and second-phase insulin secretion dynamics and glucose tolerance in the conscious mouse. Diabetes $\mathbf{6 1}$, 1700-1707 (2012).

29. Ravier, M.A. et al. Loss of connexin36 channels alters beta-cell coupling, islet synchronization of glucose-induced $\mathrm{Ca} 2+$ and insulin oscillations, and basal insulin release. Diabetes 54, 1798-1807 (2005).

30. Carvalho, C.P. et al. Beta cell coupling and connexin expression change during the functional maturation of rat pancreatic islets. Diabetologia 53, 1428-1437 (2010).

31. Serre-Beinier, V. et al. Cx36 preferentially connects beta-cells within pancreatic islets. Diabetes 49, 727-734 (2000).

32. Emfinger, C.H. et al. Beta-cell excitability and excitability-driven diabetes in adult Zebrafish islets. Physiol Rep 7, e14101 (2019).

33. Hoptak-Solga, A.D., Klein, K.A., DeRosa, A.M., White, T.W. \& Iovine, M.K. Zebrafish short fin mutations in connexin43 lead to aberrant gap junctional intercellular communication. FEBS Lett 581, 3297-3302 (2007). 
34. Govindan, J., Tun, K.M. \& Iovine, M.K. Cx43-Dependent Skeletal Phenotypes Are Mediated by Interactions between the Hapln1a-ECM and Sema3d during Fin Regeneration. PLoS One 11, e0148202 (2016).

35. Daane, J.M. et al. Bioelectric-calcineurin signaling module regulates allometric growth and size of the zebrafish fin. Sci Rep 8, 10391 (2018).

36. Iovine, M.K., Higgins, E.P., Hindes, A., Coblitz, B. \& Johnson, S.L. Mutations in connexin43 (GJA1) perturb bone growth in zebrafish fins. Dev Biol 278, 208-219 (2005).

37. Tarifeno-Saldivia, E. et al. Transcriptome analysis of pancreatic cells across distant species highlights novel important regulator genes. BMC Biol 15, 21 (2017).

38. Yang, Y.H., Manning Fox, J.E., Zhang, K.L., MacDonald, P.E. \& Johnson, J.D. Intraislet SLIT-ROBO signaling is required for beta-cell survival and potentiates insulin secretion. Proc Natl Acad Sci U S A 110, 16480-16485 (2013).

39. Albrecht, T., Zhao, Y., Nguyen, T.H., Campbell, R.E. \& Johnson, J.D. Fluorescent biosensors illuminate calcium levels within defined beta-cell endosome subpopulations. Cell Calcium 57, 263-274 (2015).

40. Benninger, R.K., Zhang, M., Head, W.S., Satin, L.S. \& Piston, D.W. Gap junction coupling and calcium waves in the pancreatic islet. Biophys J 95, 5048-5061 (2008).

41. Johnston, N.R. et al. Beta Cell Hubs Dictate Pancreatic Islet Responses to Glucose. Cell Metab 24, 389-401 (2016).

42. Stozer, A. et al. Functional connectivity in islets of Langerhans from mouse pancreas tissue slices. PLoS Comput Biol 9, e1002923 (2013).

43. Panzer, J.K. et al. Pancreas tissue slices from organ donors enable in situ analysis of type 1 diabetes pathogenesis. JCI Insight 5 (2020).

44. Salem, V. et al. Leader beta-cells coordinate $\mathrm{Ca}(2+)$ dynamics across pancreatic islets in vivo. Nat Metab 1, 615-629 (2019).

45. Adams, M.T. et al. Synchronized $\beta$ cell response to glucose is lost concomitant with loss of islet architecture in Robo deficient islets of Langerhans <em >in vivo</em>. bioRxiv, 2019.2012.2011.873471 (2020).

46. Stevenson, T.J. et al. Hypoxia disruption of vertebrate CNS pathfinding through ephrinB2 Is rescued by magnesium. PLoS Genet 8, e1002638 (2012).

47. Li, Z., Wen, C., Peng, J., Korzh, V. \& Gong, Z. Generation of living color transgenic zebrafish to trace somatostatin-expressing cells and endocrine pancreas organization. Differentiation 77, 128-134 (2009).

48. Zecchin, E. et al. Distinct delta and jagged genes control sequential segregation of pancreatic cell types from precursor pools in zebrafish. Dev Biol 301, 192-204 (2007).

49. Mongera, A. et al. Genetic lineage labeling in zebrafish uncovers novel neural crest contributions to the head, including gill pillar cells. Development 140, 916-925 (2013).

50. Wang, Y.J., Park, J.T., Parsons, M.J. \& Leach, S.D. Fate mapping of ptfla-expressing cells during pancreatic organogenesis and regeneration in zebrafish. Dev Dyn 244, 724735 (2015).

51. Jin, S.W., Beis, D., Mitchell, T., Chen, J.N. \& Stainier, D.Y. Cellular and molecular analyses of vascular tube and lumen formation in zebrafish. Development 132, 5199-5209 (2005).

52. Muto, A. et al. Activation of the hypothalamic feeding centre upon visual prey detection. Nat Commun 8, 15029 (2017). 
bioRxiv preprint doi: https://doi.org/10.1101/202011.04.368084; this version posted November 5, 2020. The copyright holder for this preprint

(which was not certified by peer review) is the author/funder, who has granted bioRxiv a license to display the preprint in perpetuity. It is made available under aCC-BY 4.0 International license.

509 53. Ustundag, U.V. et al. White LED Light Exposure Inhibits the Development and

510 Xanthophore Pigmentation of Zebrafish Embryo. Sci Rep 9, 10810 (2019).

512 


\section{Figure legends}

514

515

516

517

518

519

520

521

522

523

524

525

526

527

528

529

530

531

532

533

534

535

536

537

538

539

540

541

542

543

544

545

546

\section{Figure 1. Pancreatic islet cell activity is visualized in vivo with preserved vascular and} neural networks. A. Wholemount immunostaining of wild-type zebrafish at 100 hours post fertilization (hpf) for acetylated Tubulin (nerves), $T g(k d r l$ :GFP) expression (vessels), and Insulin (beta cells), and counterstaining with DAPI (DNA). B. 100 hpf $T g$ (ins:mCardinal); $T g$ (sst2:RFP); $T g(g c g a: G F P)$ zebrafish stained with DAPI (DNA). C. Mean distance of pancreatic islet cells to islet core reveals a beta cell core and alpha cell mantle; mean \pm S.E.M., n=11 animals; p-values from ANOVA. D. 100 hpf Et(1121A:GALAFF); Tg(UAS:GCaMP6s); Tg(ins:mCardinal); $T g($ sst2:RFP) zebrafish stained with DAPI (DNA). E. $100 \mathrm{hpf}$ Et(1121A:GAL4FF); Tg(UAS:GCaMP6s); Tg(ins:mCardinal) zebrafish stained for Glucagon (alpha cells) and DNA. F. Schematic of documented interactions between beta, delta, and alpha cells and of intracellular calcium recordings in each of these cell types. Maximum intensity projections or single planes are presented; A, anterior; $\mathrm{D}$, dorsal; V, vagus nerve; $\mathrm{P}$, pancreas.

\section{Figure 2. Chronic inhibition of synaptic transmission disrupts islet cell activity. A.}

Schematic of transplants to generate chimeras with endodermal organs derived entirely from donor embryos. B. Whole larva free glucose level measurements at $100 \mathrm{hpf}$, mean \pm S.E.M., $\mathrm{n}=24-32$ batches of 5 larvae per replicate. C. Quantification of primary islet mass. D. Mean distance of pancreatic islet cells to islet core, mean \pm S.E.M., $n=21-29$ animals, $p$-values from ttests. E. Normalized calcium traces of pancreatic islet cells (including delta, beta, alpha, and unidentified cells). Individual islet cells were assigned to a cell type and given a cell id; LG, basal condition; HG, glucose treated condition. F. Correlation matrices of islet cell activity. Individual islet cells were assigned to a cell type and given a cell id, and average correlation coefficients for given cell pairs (matrix row-column intersects) were calculated for LG (basal condition; bottom left triangle) and HG (glucose treated condition; top right triangle). G. Average beta cell correlation coefficients in individual larvae, $n=5-8$ animals, $p$-values from $t$ tests. H. Average beta cell correlation coefficients with cell distance distribution from 1 (close) to 10 (far), mean \pm S.E.M. (dotted lines). I. Area over the curve (AOC) analysis of $\mathrm{H}$, mean \pm S.E.M., n=5-8 animals, p-values from t-tests. J-L. Fraction time analysis of heterotypic deltabeta $(\mathbf{J})$, alpha-delta $(\mathbf{K})$ and alpha-beta $(\mathbf{L})$ cell pairs, mean \pm S.E.M., $n=32-160$ cell pairs; magenta circle, active state; cyan circle, silent state.

Figure 3. Targeted ablation studies reveal the crucial role of peri-islet neurons for islet cell activity. A. Schematic of lineage tracing of neural crest cells in Tg(sox10:CreERT2, myl7:GFP); Tg(ubb:loxP-CFP-loxP-nuc-mCherry); Tg(ins:mCardinal); Et(1121A:GAL4FF); Tg(UAS:GCaMP6s) zebrafish following $5 \mu \mathrm{M}$ tamoxifen (TM) treatment from 16 to 24 hpf and 
staining at $108 \mathrm{hpf}$. B. Wholemount immunostaining at $100 \mathrm{hpf}$ for mCherry expression (neural crest derived cells) and counterstaining with DAPI (DNA). Yellow arrowheads point to neural crest cells positive for GCaMP6s expression. C. Schematic of two-photon ablation experiment. D. Normalized calcium traces of pancreatic islet cells (including delta, beta, alpha, and unidentified cells). Individual islet cells were assigned to a cell type and given a cell id; LG, basal condition; HG, glucose treated condition. E. Correlation matrices of islet cell activity; LG, basal condition; HG, glucose treated condition. F. Average beta cell correlation coefficients in individual larvae, $n=6-8$ animals, $\mathrm{p}$-values from t-tests. G. Average beta cell correlation coefficients with variable cell distance, mean \pm S.E.M. (dotted lines). H. Area over the curve (AOC) analysis of $\mathrm{G}$, mean \pm S.E.M., $n=5-8$ animals, $\mathrm{p}$-values from t-tests. I-K. Fraction time analysis of heterotypic delta-beta $(\mathbf{I})$, alpha-delta $(\mathbf{J})$ and alpha-beta $(\mathbf{K})$ cell pairs, mean \pm S.E.M., $n=63-145$ cell pairs; magenta circle, active state; cyan circle, silent state.

\section{Figure 4. Acute optogenetic inhibition of neurotransmitter release disrupts islet cell} activity. A. Whole larva free glucose level measurements of Tg(elavl3:sypb-miniSOG2-P2A$m S$ carlet) zebrafish at $110 \mathrm{hpf}$, mean \pm S.E.M., $\mathrm{n}=11-19$ batches of 5 larvae per replicate. B. Normalized calcium traces of pancreatic islet cells (including delta, beta, alpha, and unidentified cells). Individual islet cells were assigned to a cell type and given a cell id; LG, basal condition; HG, glucose treated condition. C. Correlation matrices of islet cell activity; LG, basal condition; HG, glucose treated condition. D. Average beta cell correlation coefficients in individual larvae, $n=6-7$ animals, $p$-values from t-tests. E. Average beta cell correlation coefficients with variable cell distance, mean \pm S.E.M. (dotted lines). F. Area over the curve (AOC) analysis of E, mean \pm S.E.M., $n=6-7$ animals, p-values from t-tests. G-I. Fraction time analysis of heterotypic delta-beta $(\mathbf{G})$, alpha-delta $(\mathbf{H})$ and alpha-beta $(\mathbf{I})$ cell pairs, mean \pm S.E.M., $n=71-119$ cell pairs; magenta circle, active state; cyan circle, silent state.

Figure 5. Coordination of beta cell activity is in part mediated by $\mathrm{Cx43}$ gap junctions. A. Wholemount immunostaining of $100 \mathrm{hpf}$ Et(1121A:GALAFF); $\operatorname{Tg}(U A S: G C a M P 6 s)$; Tg(ins:mCardinal) zebrafish for Connexin 43, and counterstaining with DAPI (DNA). B. Schematic of cx43 mutant experiment. C. Et(1121A:GALAFF); Tg(UAS:GCaMP6s); Tg(ins:mCardinal); $T g($ sst $2: R F P) c x 43^{+/+}, c x 43^{+/-}$, and $c x 43^{-/-}$larvae imaged at 100 hpf. D. Normalized calcium traces of pancreatic islet cells (including delta, beta, alpha, and unidentified cells). Individual islet cells were assigned to a cell type and given a cell id; LG, basal condition; HG, glucose treated condition. E. Correlation matrices of islet cell activity. F. Average beta cell correlation coefficients in individual larvae, $n=8-14$ animals, $p$-values from t-tests. $\mathbf{G}$. Average beta cell correlation coefficients with variable cell distance, mean \pm S.E.M. (dotted 
bioRxiv preprint doi: https://doi.org/10.1101/2020.11.04.368084; this version posted November 5, 2020. The copyright holder for this preprint (which was not certified by peer review) is the author/funder, who has granted bioRxiv a license to display the preprint in perpetuity. It is made available under aCC-BY 4.0 International license.

581 lines), $\mathrm{n}=8-14$ animals. H. Area over the curve (AOC) analysis of G, mean \pm S.E.M., $\mathrm{n}=8-14$

582 animals, p-values from ANOVA.

583

584 


\section{Supplemental figure legends}

\section{Figure 2 - Figure Supplement 1. Glucose treatment elevates whole larva glucose levels.} Zebrafish at $100 \mathrm{hpf}$ were treated with $75 \mathrm{mM}$ glucose in egg water for $1 \mathrm{hr}$. Whole larva free glucose level measurements at $101 \mathrm{hpf}$, mean \pm SEM, $\mathrm{n}=11-19$ batches of 5 larvae per replicate.

Figure 4 - Figure Supplement 1. Swimming activity is reduced following blue light exposure in Tg(elavl3:sypb-miniSOG2-P2A-mScarlet) larvae. A. Swimming activity of Tg(elavl3:sypb-miniSOG2-P2A-mScarlet) zebrafish at $110 \mathrm{hpf}$ was tracked pre- and post- blue light exposure for $5 \mathrm{~min}$. Green lines show tracks at the end of the time-lapse. B-C. Quantification of swimming activity of Tg(elavl3:sypb-miniSOG2-P2A-mScarlet) zebrafish at 110 hpf, mean \pm S.E.M., $n=21-23$ animals, p-values from ANOVA and t-tests, respectively. D. Schematic of optogenetic neural inhibition experiment.

\section{Figure 5 - Figure Supplement 1. Expression of gap junction genes in FACS sorted} zebrafish islet cells. Expression profile of gap junction genes from in-house and published RNAseq datasets of FACS sorted zebrafish pancreatic beta, alpha, and delta cells at embryonic (24-28 hpf), early larval (96-100 hpf), and adult stages ${ }^{37}$.

\section{Figure 5 - Figure Supplement 2. Changes in heterotypic interactions between pancreatic} islet cells in cx43 mutants. A. $c x 43^{+/+}, c x 43^{+/}$, and $c x 43^{-/-}$larvae imaged at $100 \mathrm{hpf}$. B. Body length measurements at $100 \mathrm{hpf}$, mean \pm S.E.M., $\mathrm{n}=18$-26 animals. C. Whole larva free glucose level measurements at $100 \mathrm{hpf}$, mean \pm S.E.M., $\mathrm{n}=23-51$ batches of 5 larvae per replicate. D-F. Fraction time analysis of heterotypic delta-beta (D), alpha-delta (E) and alpha-beta (F) cell pairs, mean \pm SEM, $n=165-293$ cell pairs; magenta circle, active state; cyan circle, silent state. G. Fasting blood glucose levels in adults, mean \pm SEM, $n=5-11$ animals, $p$-values from ANOVA.

Figure 1 - Movie Supplement 1. 100 hpf Et(1121A:GALAFF); Tg(UAS:GCaMP6s); Tg(ins:mCardinal); $T g($ sst2:RFP) zebrafish stained with DAPI (DNA).

Figure 1 - Movie Supplement 2. Intracellular calcium dynamics in pancreatic islet cells (including delta, beta, alpha, and unidentified cells) in $100 \mathrm{hpf}$ Et(1121A:GALAFF);

Tg(UAS:GCaMP6s); Tg(ins:mCardinal); Tg(sst2:RFP) zebrafish.

Figure 5 - Movie Supplement 1. Intracellular calcium dynamics in pancreatic islet cells in Et(1121A:GAL4FF); Tg(UAS:GCaMP6s); Tg(ins:mCardinal); $T g\left(\right.$ sst2:RFP) $c \times 43^{+/+}, c \times 43^{+/}$, and $c \times 43^{-/-}$larvae imaged at $100 \mathrm{hpf}$. Normalized calcium traces of beta cells mapped to their location within the pancreatic islet. 
bioRxiv preprint doi: https://doi.org/10.1101/2020.11.04.368084; this version posted November 5, 2020. The copyright holder for this preprint

(which was not certified by peer review) is the author/funder, who has granted bioRxiv a license to display the preprint in perpetuity. It is made available under aCC-BY 4.0 International license.

\section{Figure 1}
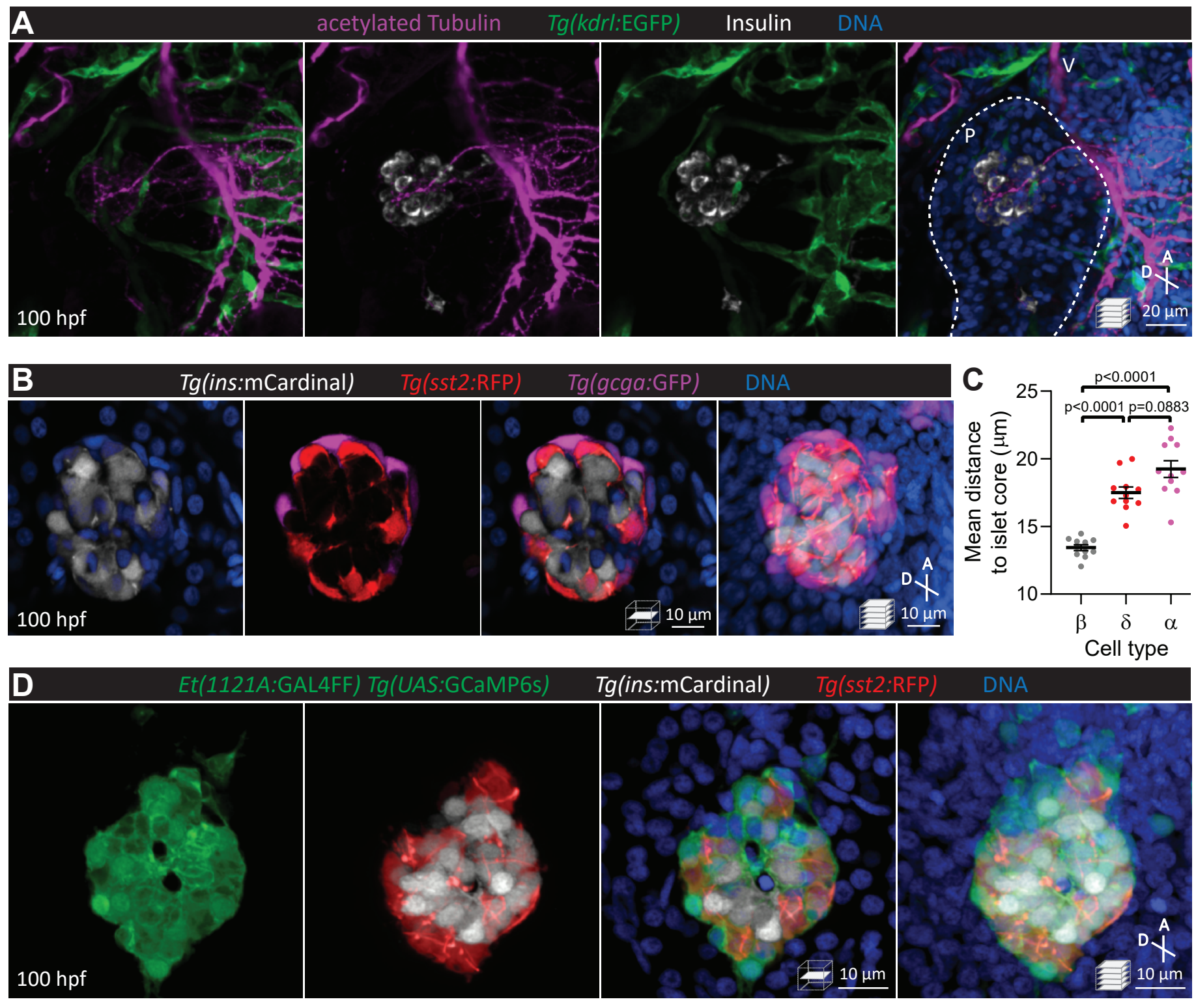

DNA

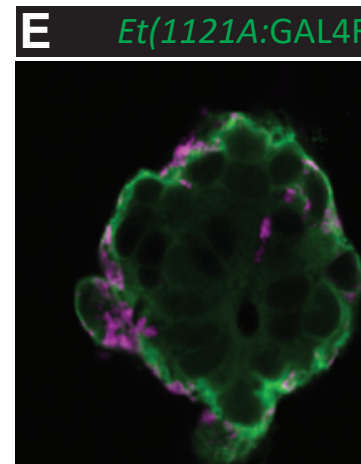

100 hpf

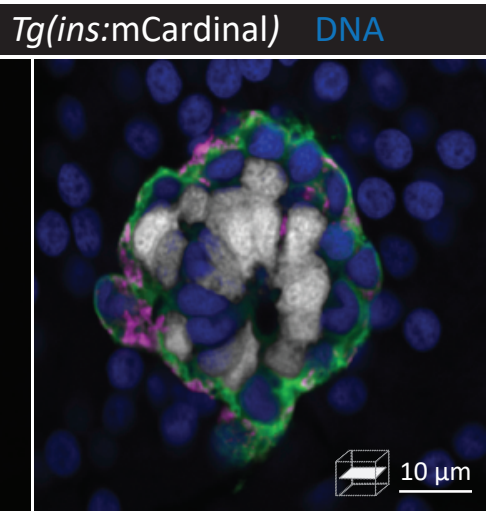

F
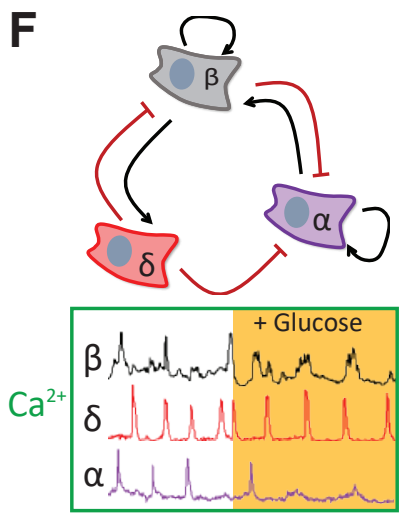
bioRxiv preprint doi: https://doi.org/10.1101/2020.11.04.368084; this version posted November 5, 2020. The copyright holder for this preprint (which was not certified by peer review) is the author/funder, who has granted bioRxiv a license to display the preprint in perpetuity. It is made available under aCC-BY 4.0 International license.

\section{Figure 2}

A

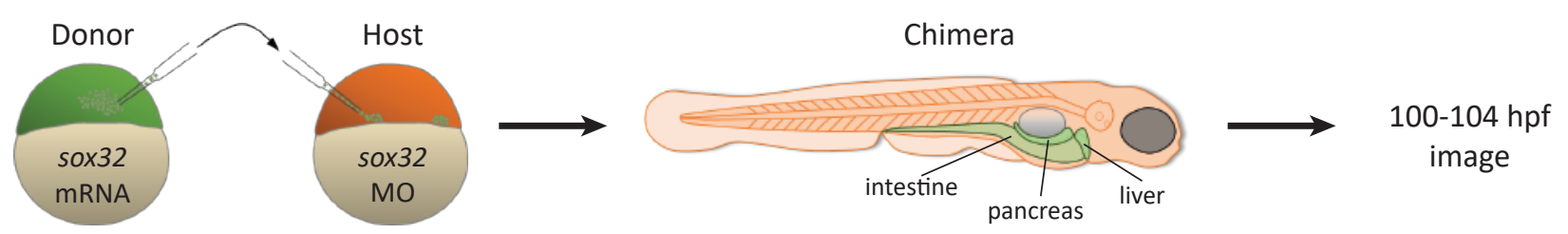

Et(1121A:GAL4FF); Tg(elavl3:GAL4-VP16);

Tg(UAS:GCaMP6s); Tg(UAS:BoTxBLC-GFP)

Tg(ins:mCardinal);

Tg(sst2:RFP)

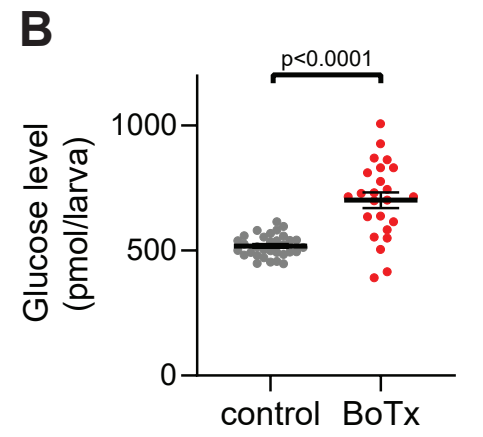

E

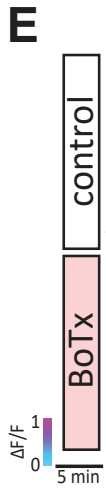

G

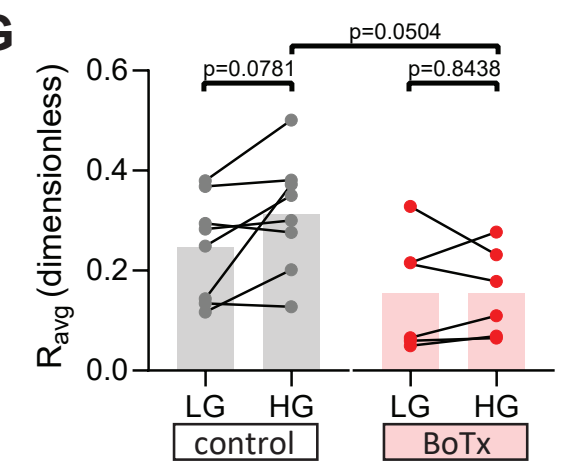

J

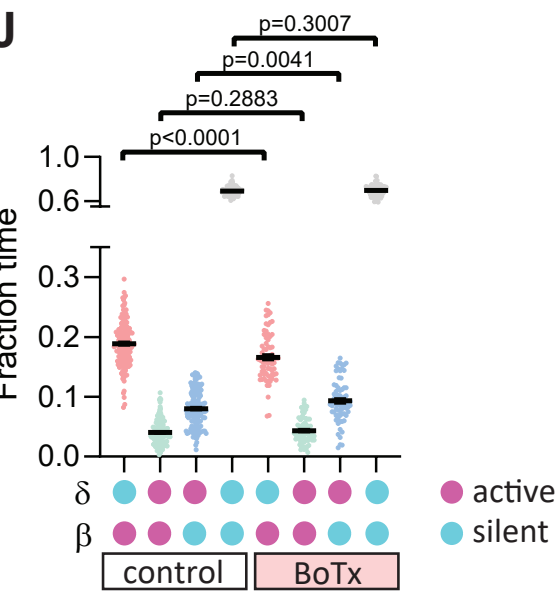

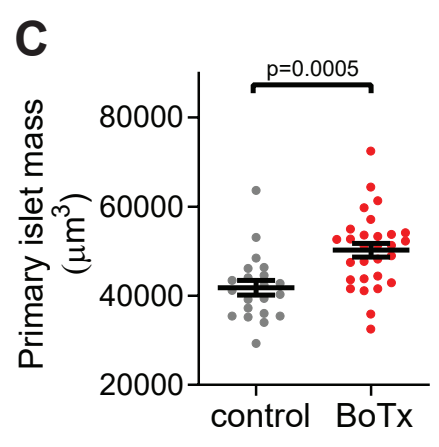
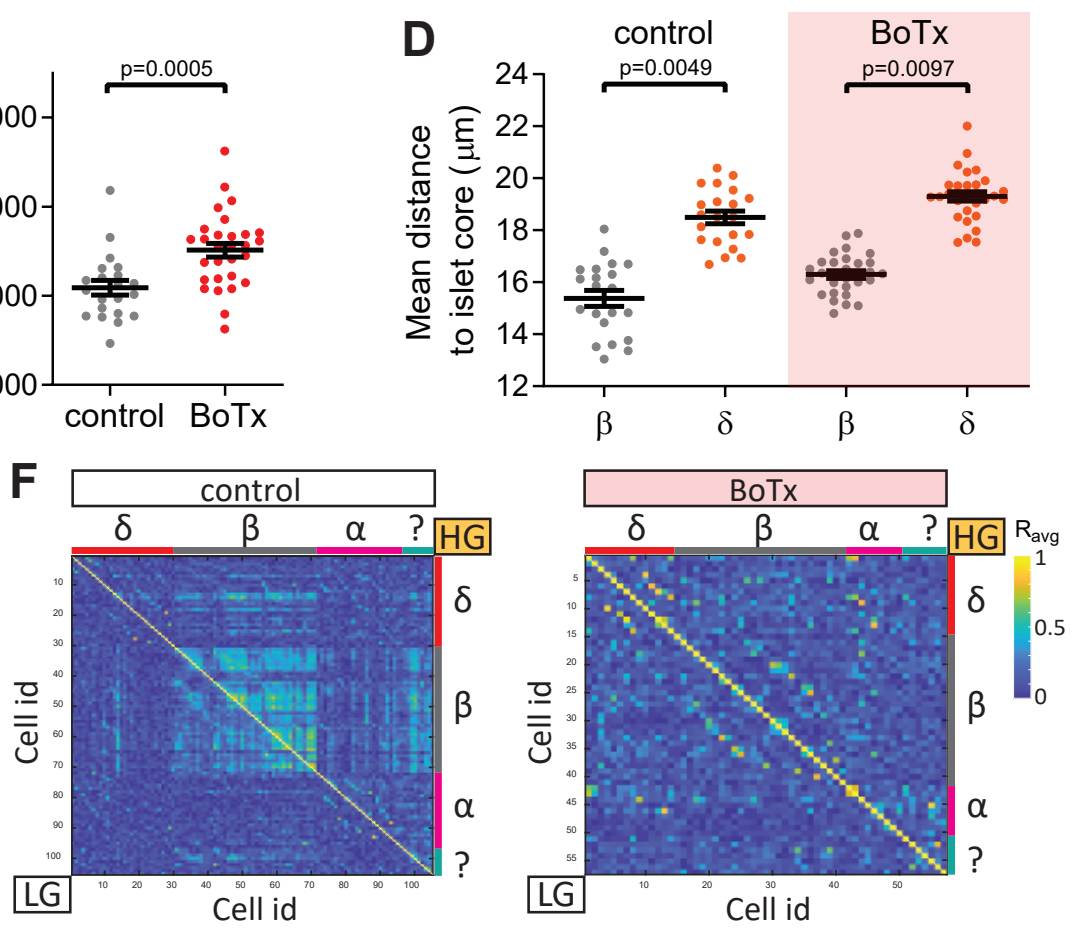

H

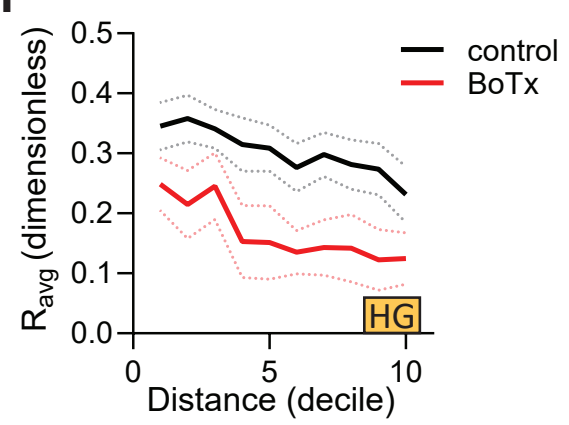

I
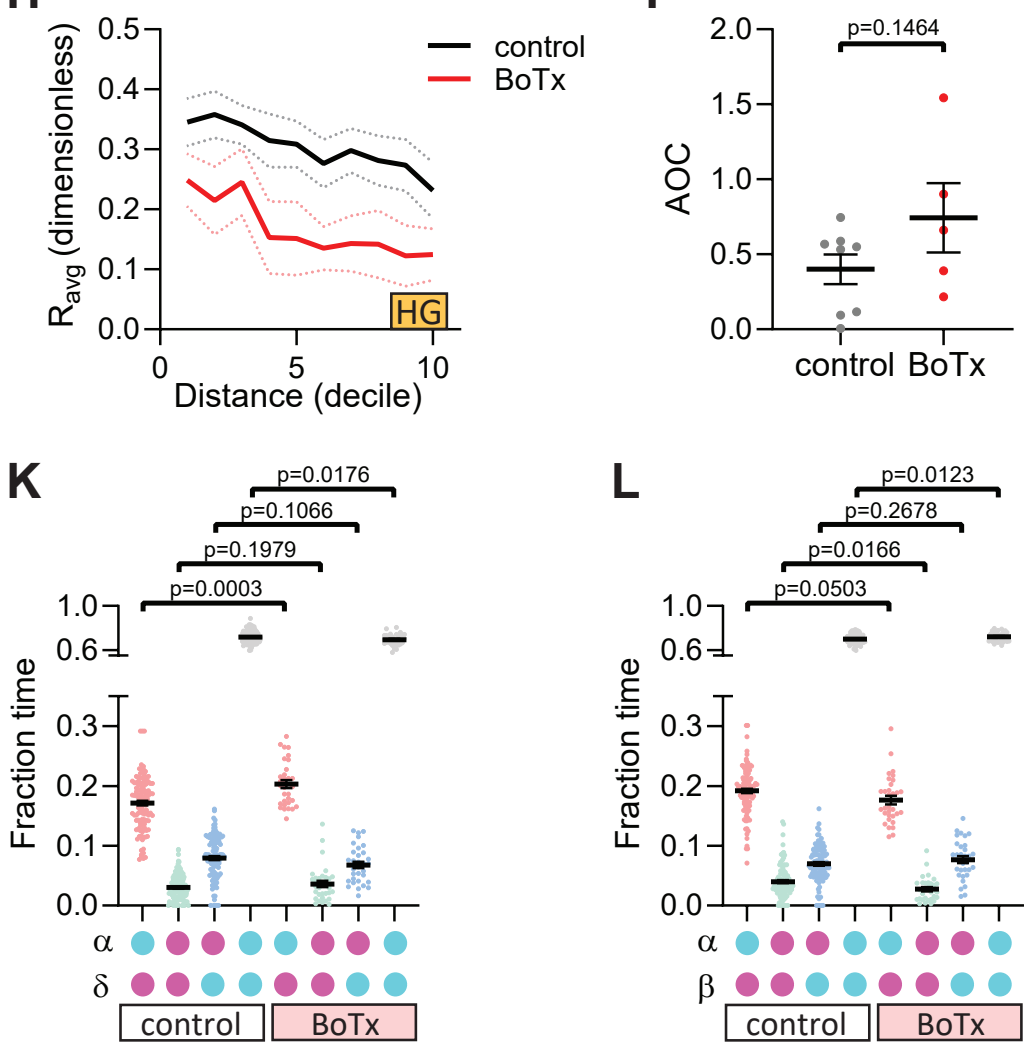
bioRxiv preprint doi: https://doi.org/10.1101/2020.11.04.368084; this version posted November 5, 2020. The copyright holder for this preprint (which was not certified by peer review) is the author/funder, who has granted bioRxiv a license to display the preprint in perpetuity. It is made available under aCC-BY 4.0 International license.

Figure 3

\section{A}

Tg(sox10:CreERT2, myl7:GFP);

Tg(ubb:IoxP-CFP-loxP-nuc-mCherry);

Et(1121A:GAL4FF);

Tg(UAS:GCaMP6s);

Tg(ins:mCardinal);

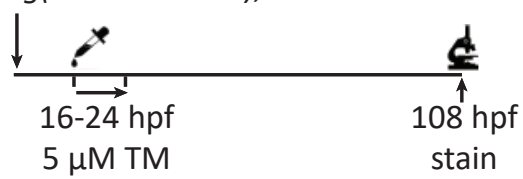

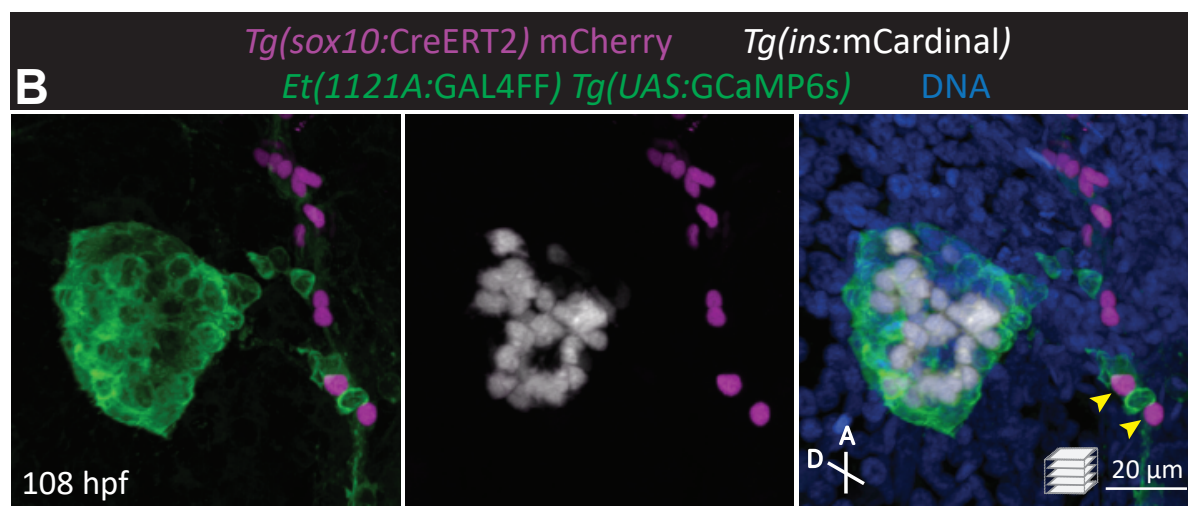

C

Et(1121A:GAL4FF);

Tg(UAS:GCaMP6s);

Tg(ins:mCardinal);

Tg(sst2:RFP)

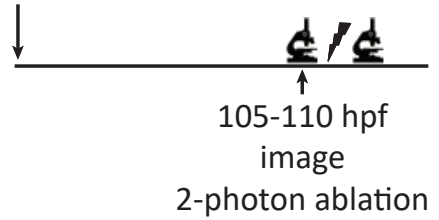

D

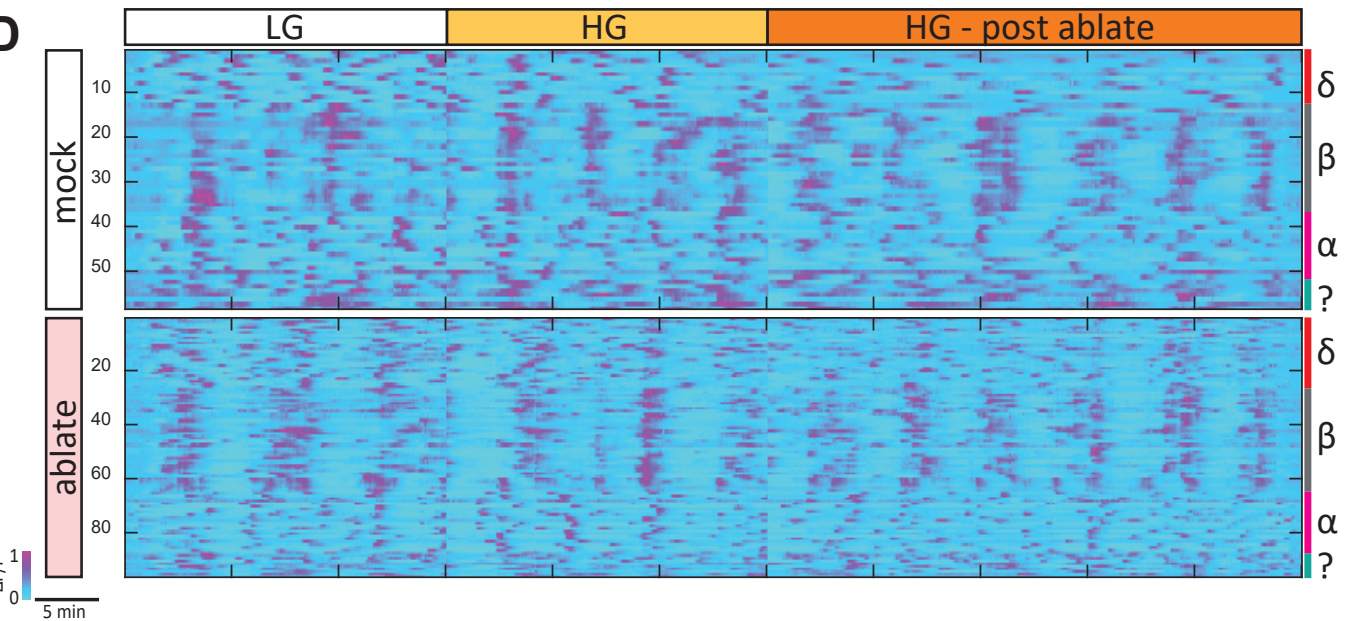

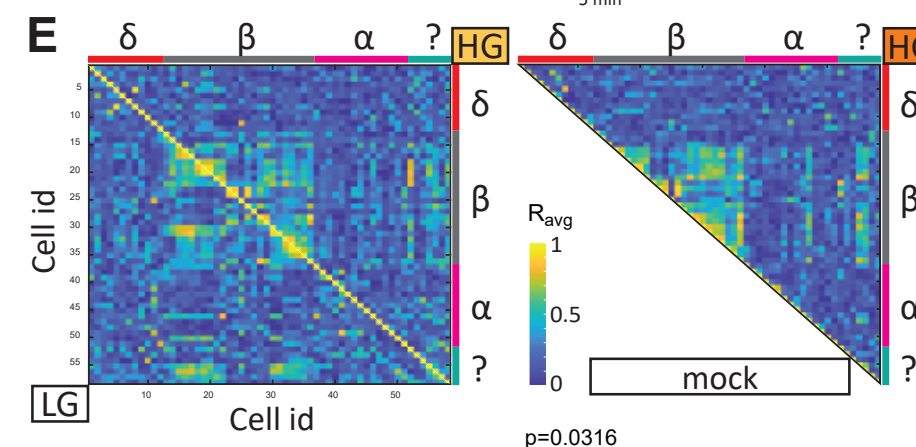

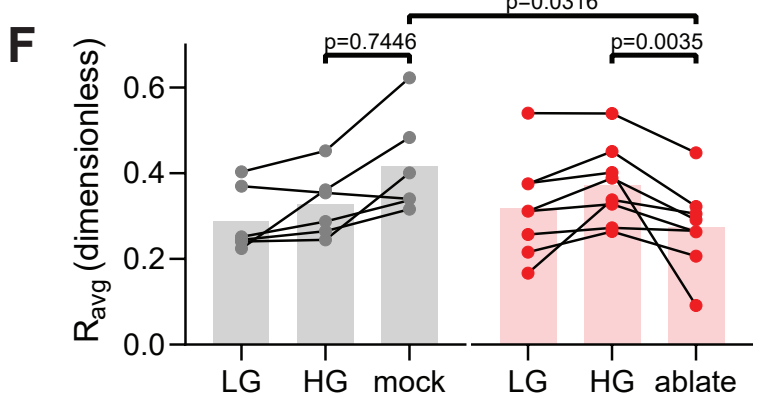

I

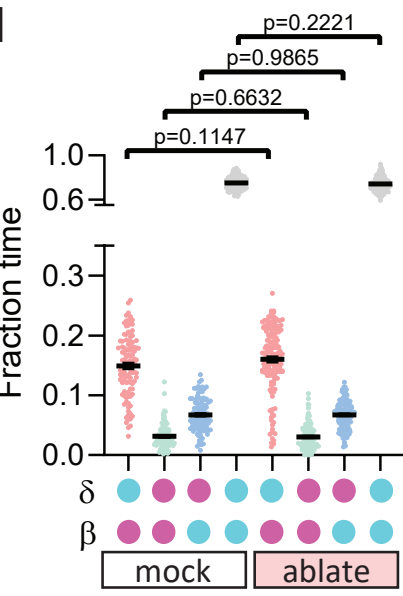

G
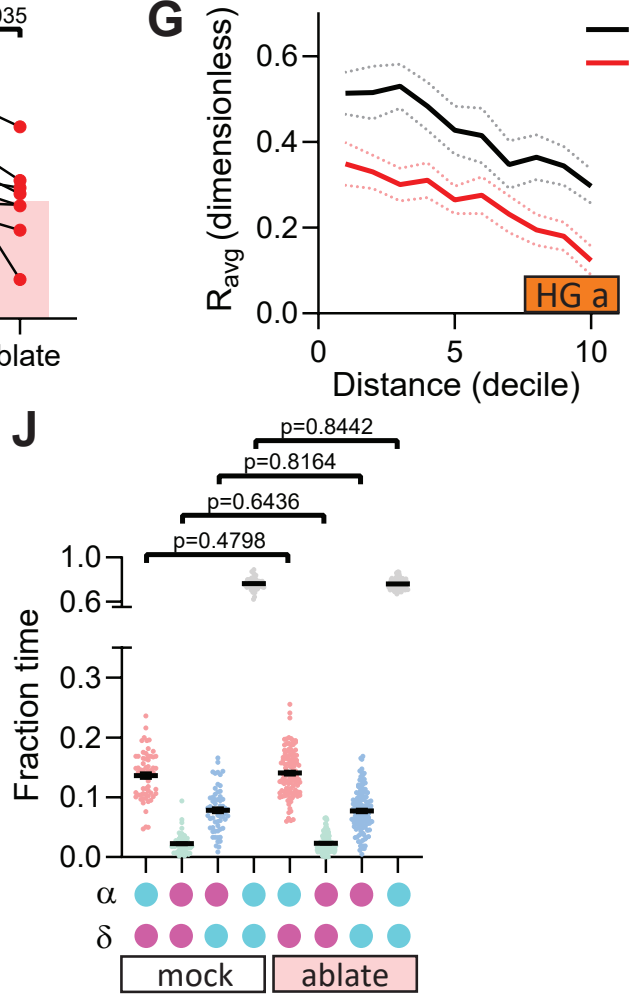
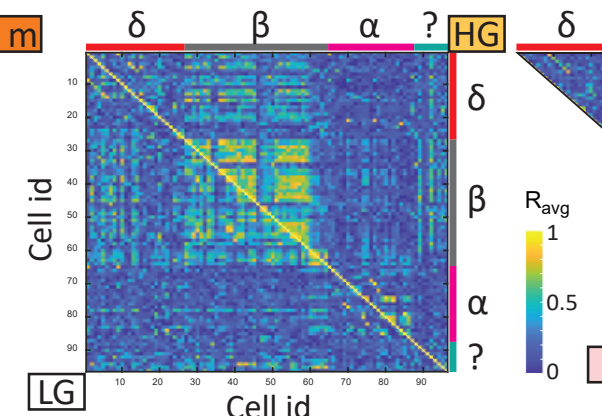

$\beta \quad \alpha$ ? HG a
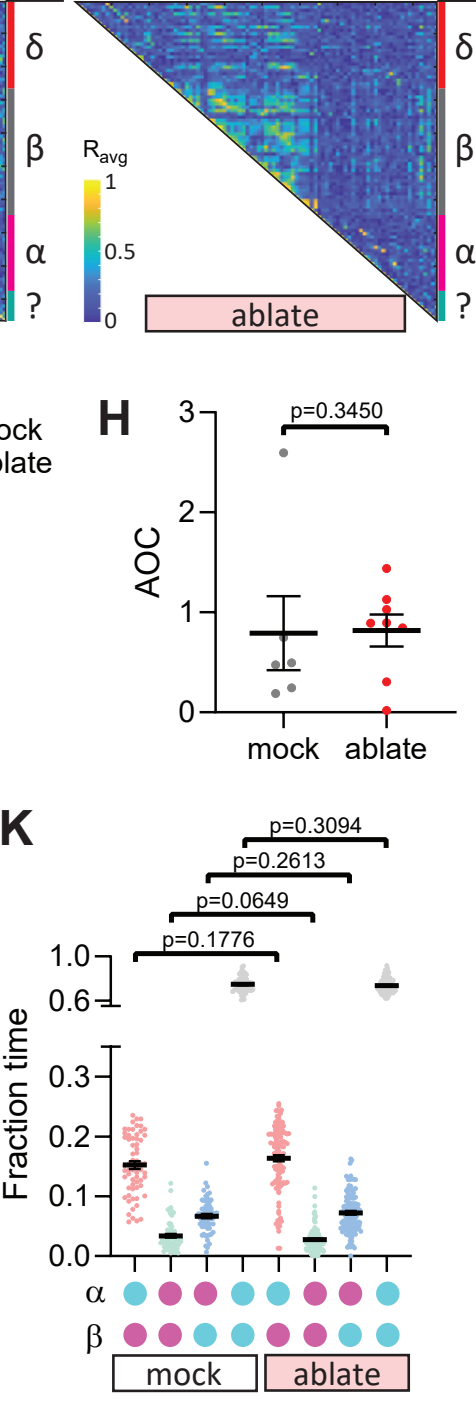
bioRxiv preprint doi: https://doi.org/10.1101/2020.11.04.368084; this version posted November 5, 2020. The copyright holder for this preprint (which was not certified by peer review) is the author/funder, who has granted bioRxiv a license to display the preprint in perpetuity. It is made available under aCC-BY 4.0 International license.

\section{Figure 4}

A

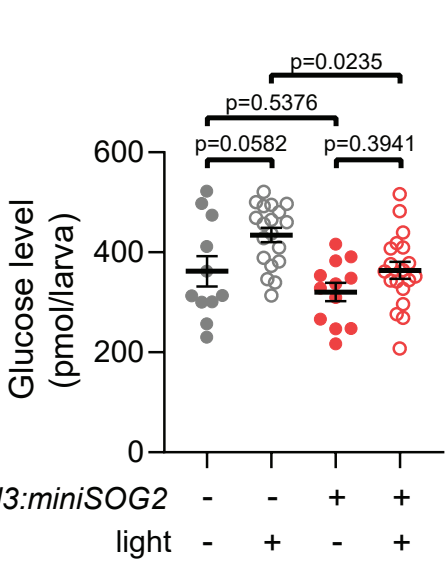

B

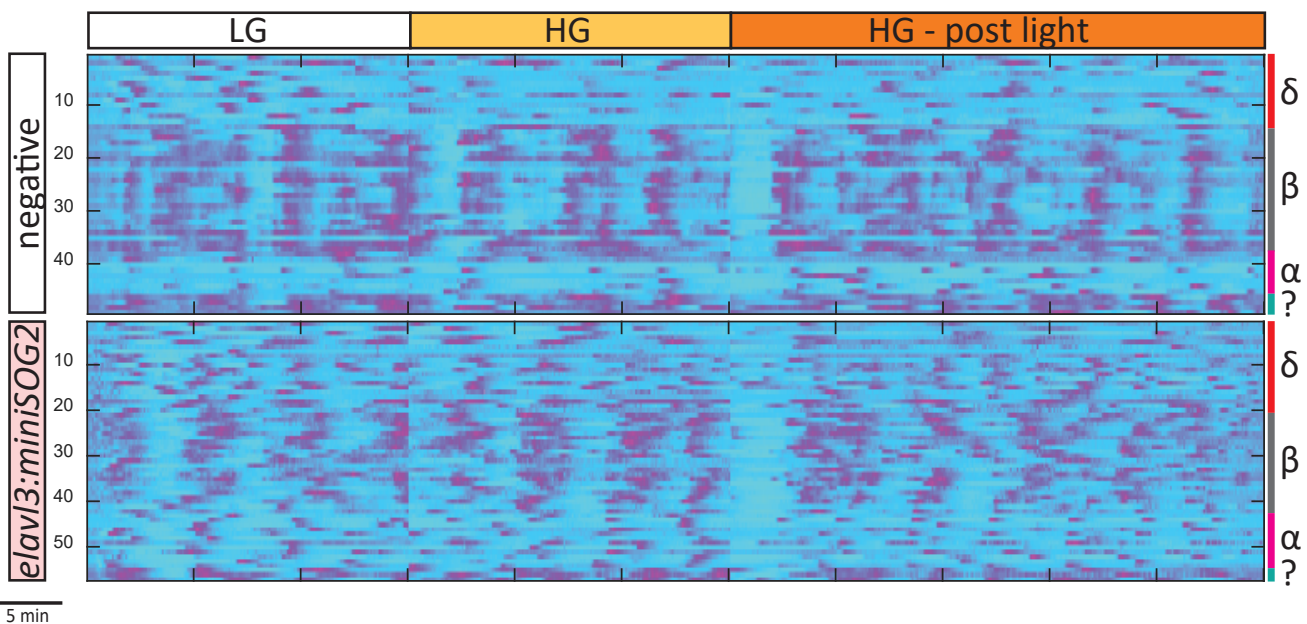

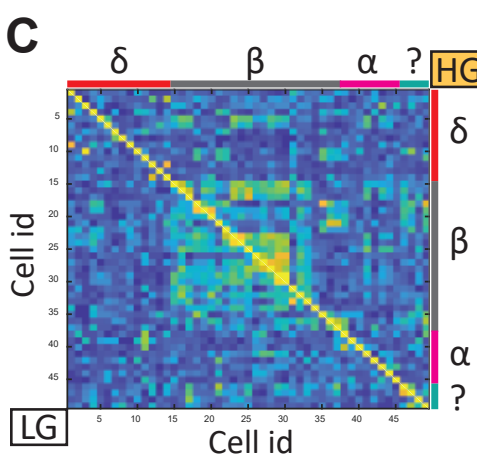

D

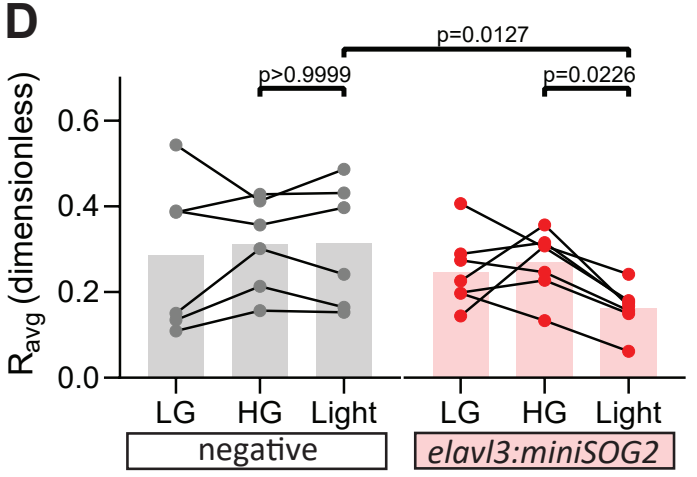

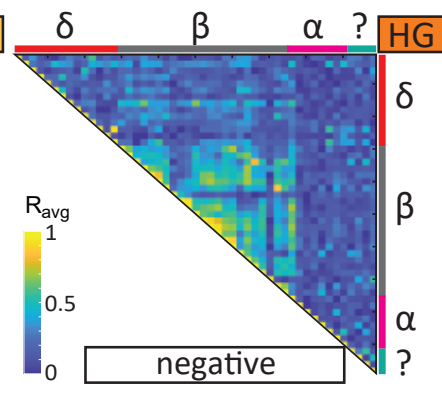

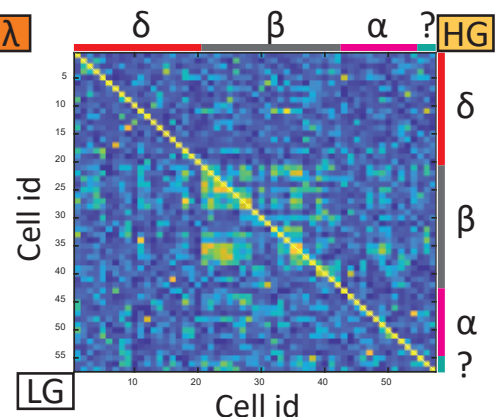

Cell id

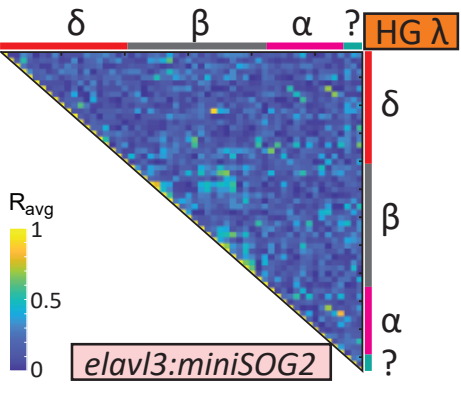

$\mathbf{E}$

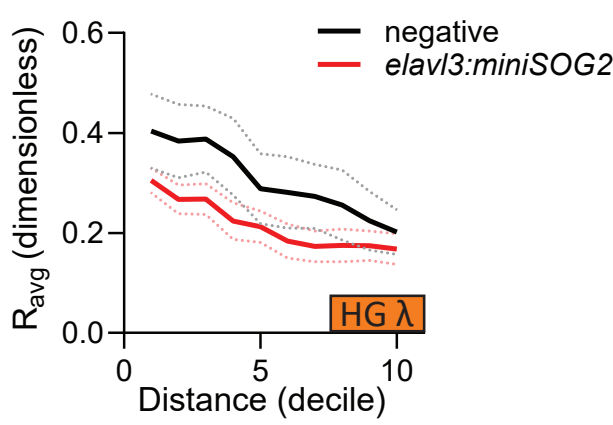

F

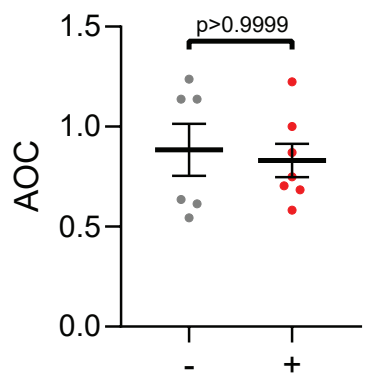

G

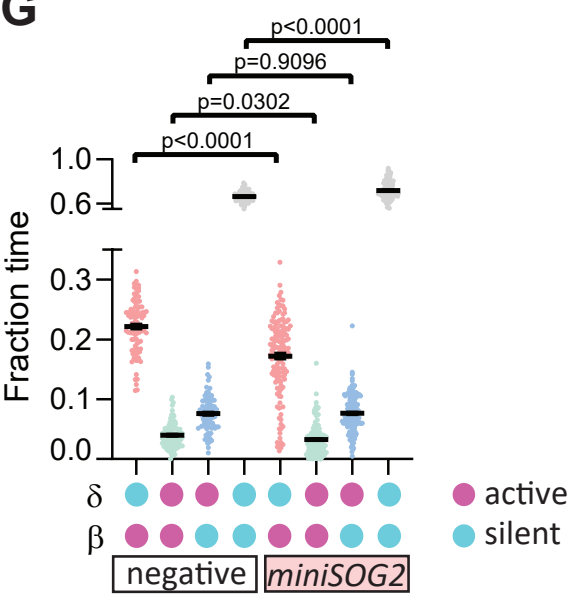

H

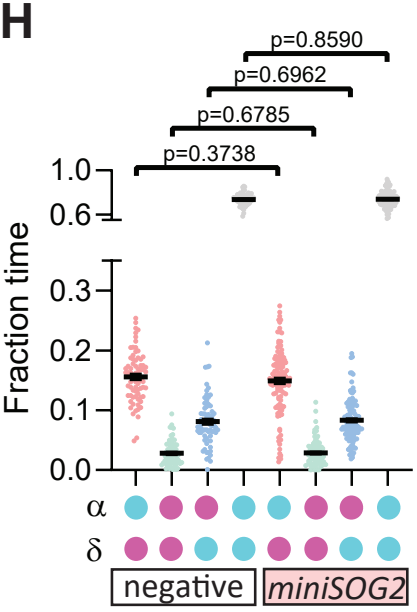

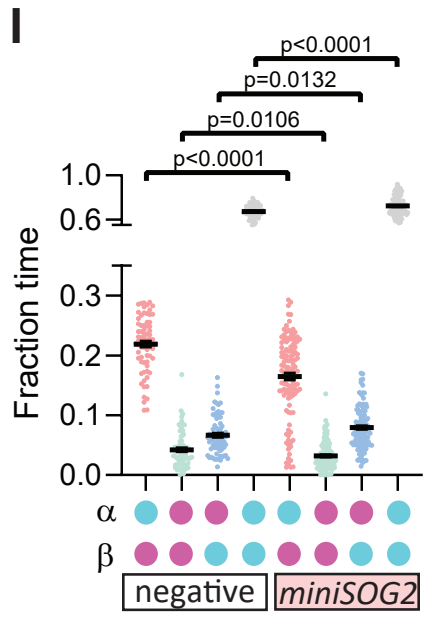


bioRxiv preprint doi: https://doi.org/10.1101/2020.11.04.368084; this version posted November 5, 2020. The copyright holder for this preprint (which was not certified by peer review) is the author/funder, who has granted bioRxiv a license to display the preprint in perpetuity. It is made available under aCC-BY 4.0 International license.

Figure 5
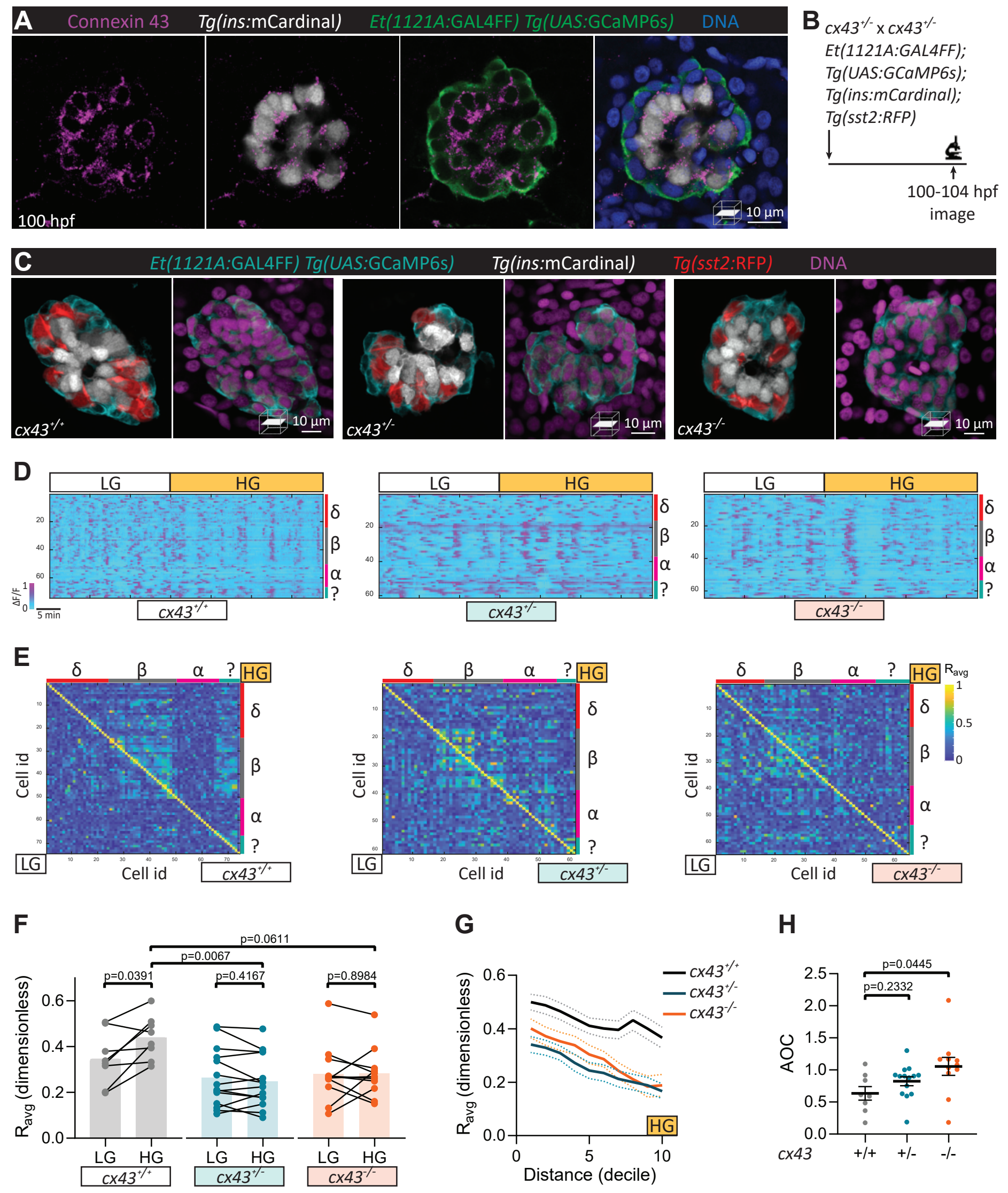

G

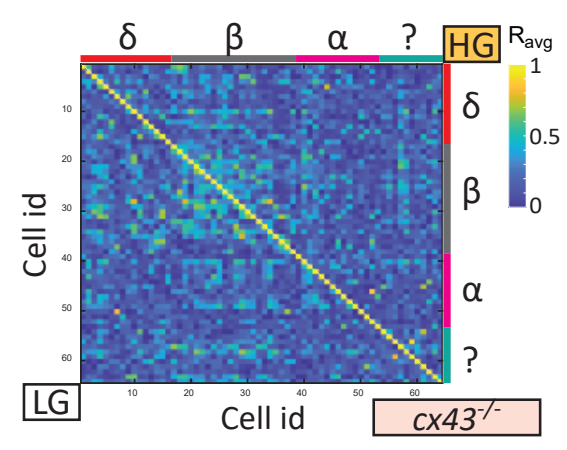

H
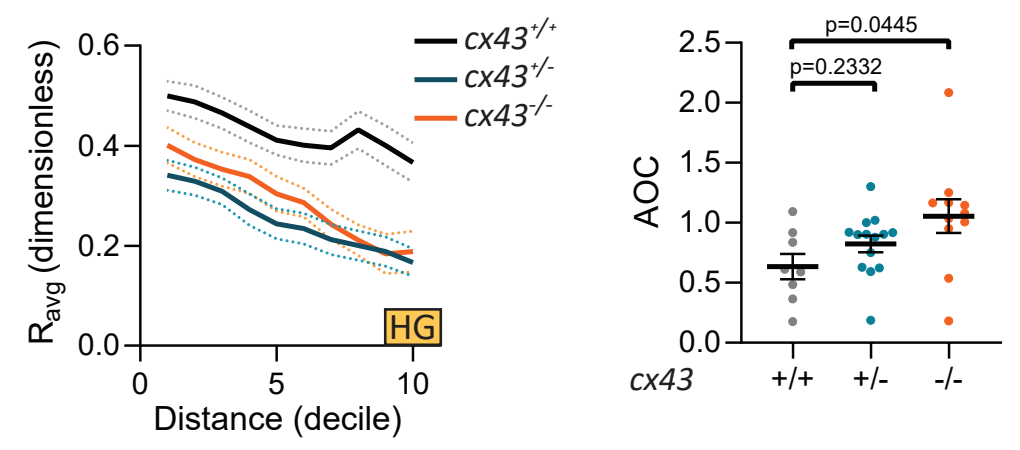
bioRxiv preprint doi: https://doi.org/10.1101/2020.11.04.368084; this version posted November 5, 2020. The copyright holder for this preprint (which was not certified by peer review) is the author/funder, who has granted bioRxiv a license to display the preprint in perpetuity. It is made available under aCC-BY 4.0 International license.

\section{Figure 2 - Figure Supplement 1}

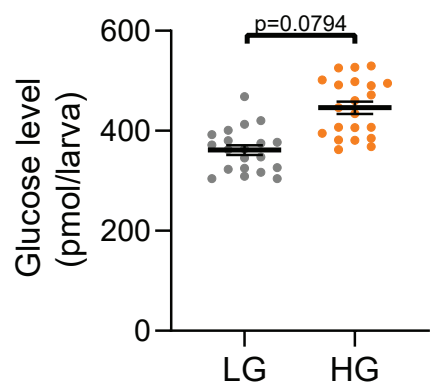


bioRxiv preprint doi: https://doi.org/10.1101/2020.11.04.368084; this version posted November 5, 2020. The copyright holder for this preprint (which was not certified by peer review) is the author/funder, who has granted bioRxiv a license to display the preprint in perpetuity. It is made available under aCC-BY 4.0 International license.

\section{Figure 4 - Figure Supplement 1}
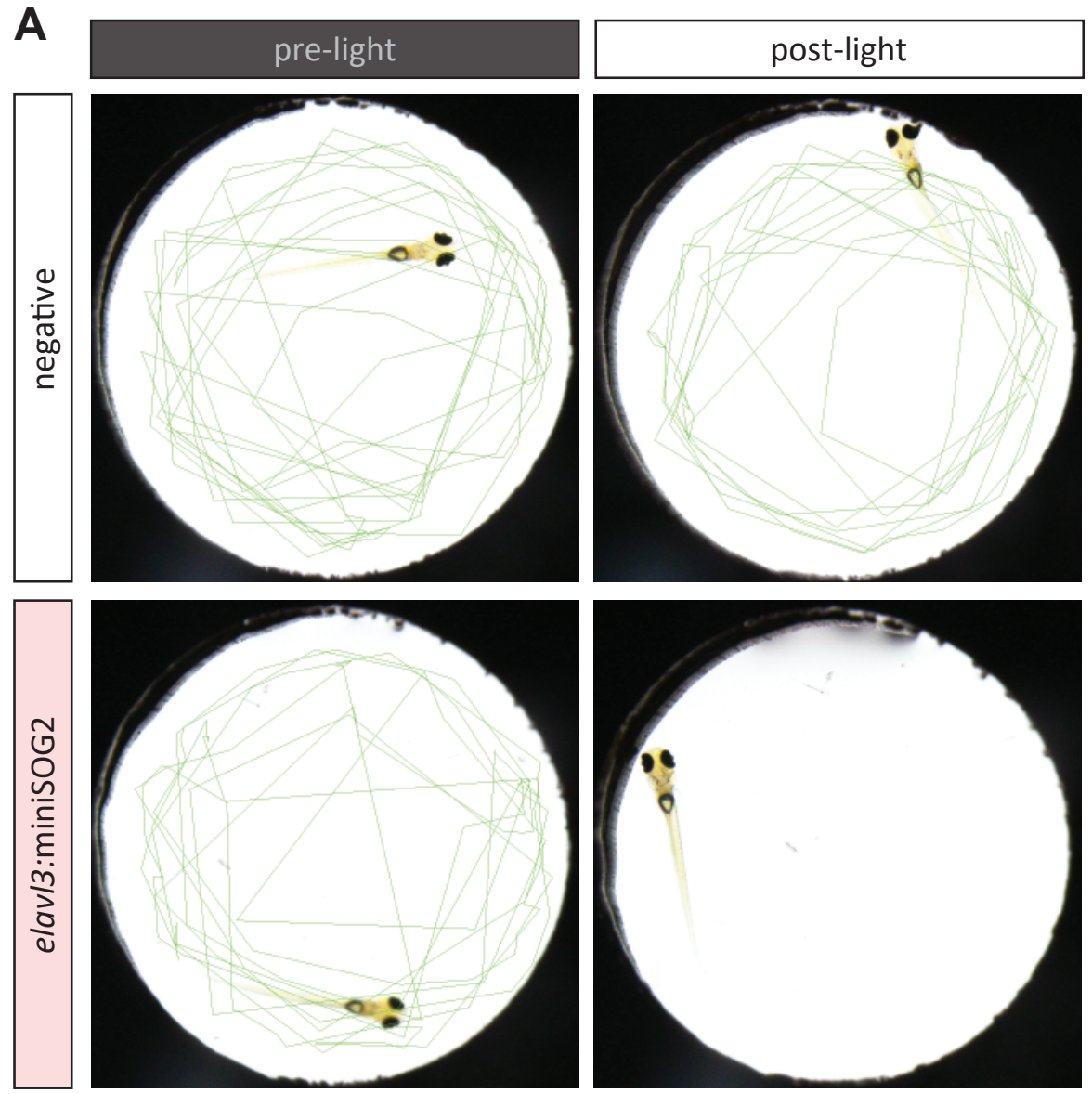

B
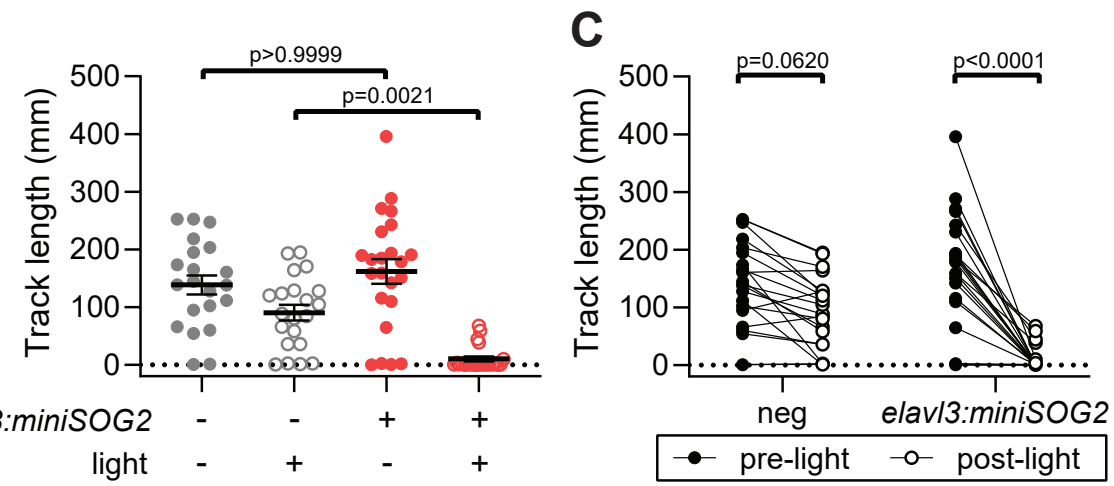

\section{D}

Tg(elavl3:sypb-miniSOG2-P2A-mScarlet);

Et(1121A:GAL4FF);

Tg(UAS:GCaMP6s);

Tg(ins:mCardinal);

$\operatorname{Tg}(s s t 2: R F P)$

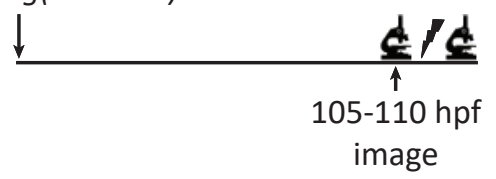

photo-inhibition 
bioRxiv preprint doi: $h t t p s: / / d o i . o r g / 10,1101 / 202011.04368084$ : this version posted November 5,2020 . The copyright holder for this preprint (which was not certified by peer review) is the author/funder, who has granted bioRxiv a license to display the preprint in perpetuity. It is made available under aCC-BY 4.0 International license.

Figure 5 - Figure Supplement 1

\begin{tabular}{|c|c|c|c|c|c|c|c|c|}
\hline & \multicolumn{2}{|c|}{ beta } & \multicolumn{3}{|c|}{ alpha } & \multicolumn{3}{|c|}{ delta } \\
\hline & \begin{tabular}{|l|l|l}
$1 \mathrm{dpf}$ & $4 \mathrm{dpf}$ \\
\end{tabular} & adult & $1 \mathrm{dpf}$ & $4 \mathrm{dpf}$ & adult & $1 \mathrm{dpf}$ & $4 \mathrm{dpf}$ & adult \\
\hline$c \times 23$ & & & & & & & & \\
\hline$c \times 27.5$ & & & & & & & & \\
\hline$c x 28.1$ & & & & & & & & \\
\hline$c \times 28.6$ & & & & & & & & \\
\hline$c \times 28.8$ & & & & & & & & \\
\hline$c \times 28.9$ & & & & & & & & \\
\hline$c x 30.3$ & & & & & & & & \\
\hline$c \times 30.9$ & & & & & & & & \\
\hline$c \times 32.2$ & & & & & & & & \\
\hline$c \times 32.3$ & & & & & & & & \\
\hline$c \times 34.4$ & & & & & & & & \\
\hline$c \times 34.5$ & & & & & & & & \\
\hline$c \times 35.4$ & & & & & & & & \\
\hline$c \times 39.4$ & & & & & & & & \\
\hline$c \times 40.8$ & & & & & & & & \\
\hline cx43 & & & & & & & & \\
\hline$c x 44.2$ & & & & & & & & \\
\hline$c x 47.1$ & & & & & & & & \\
\hline cx52.6 & & & & & & & & \\
\hline$c \times 52.7$ & & & & & & & & \\
\hline cx52.9 & & & & & & & & \\
\hline
\end{tabular}


bioRxiv preprint doi: https://doi.org/10.1101/2020.11.04 368084 this version posted November 5, 2020. The copyright holder for this preprint (which was not certified by peer review) is the author/funder, who has granted bioRxiv a license to display the preprint in perpetuity. It is made available under aCC-BY 4.0 International license.

\section{Figure 5 - Figure Supplement 2}

\section{A}

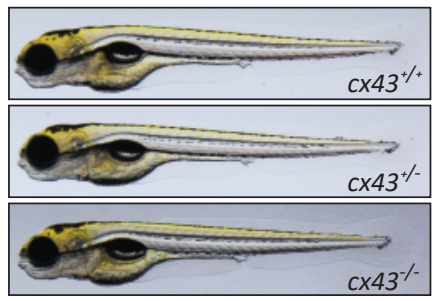

B

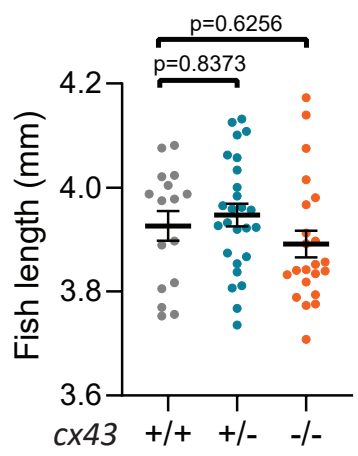

$\mathbf{E}$

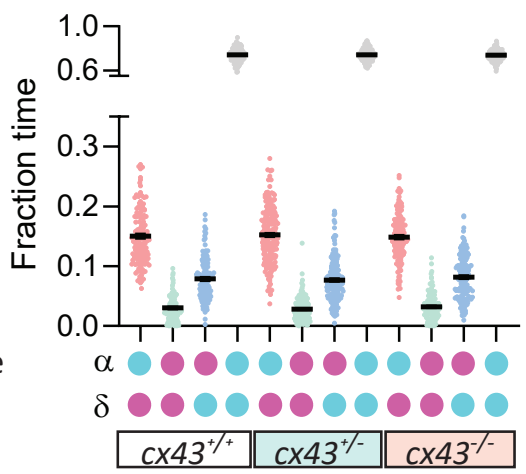

C

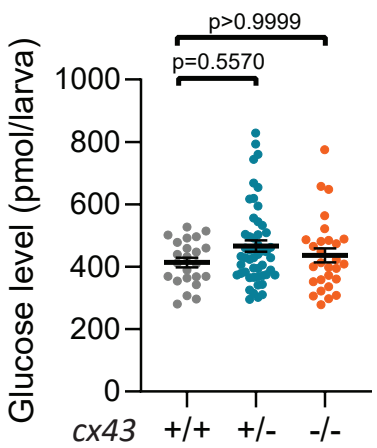

$\mathbf{F}$

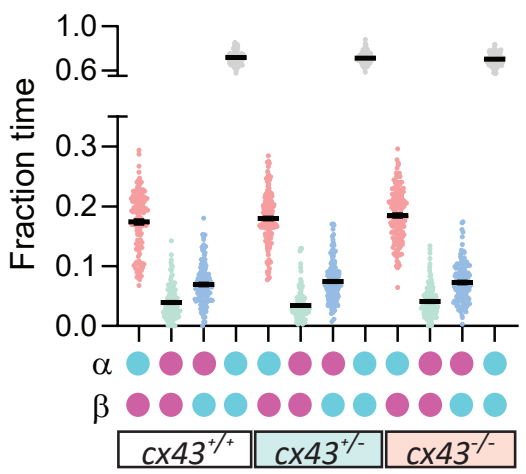

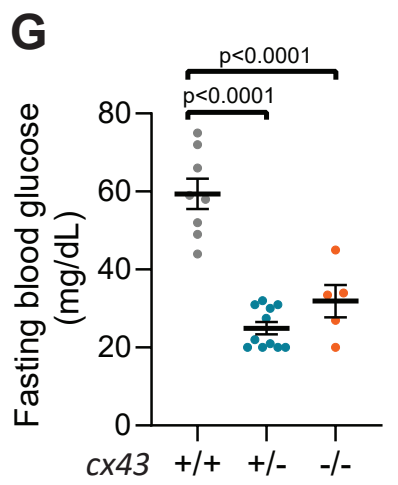




\section{Graphical Abstract}
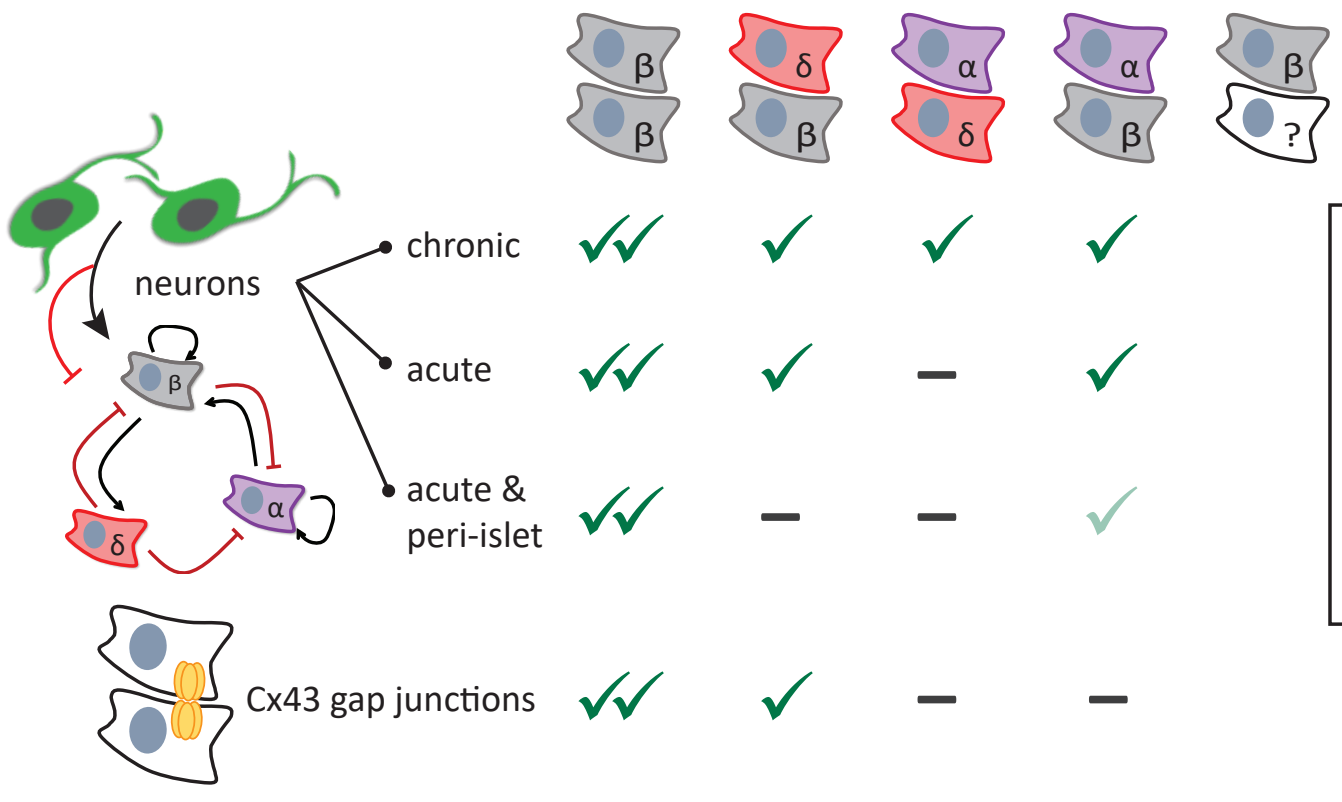

Insights from loss-of-
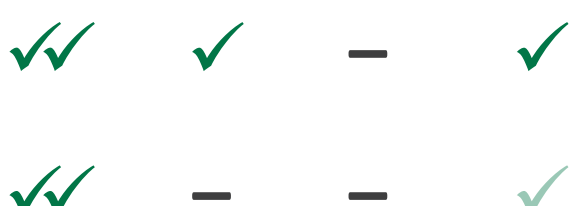

function studies:

$\sqrt{ }$ severe defects

$\checkmark$ significant defects

$\checkmark$ possible defects

- unaffected 